\title{
ASYMMETRIES IN THE TRANS-ATLANTIC MONETARY POLICY RELATIONSHIP: DOES THE ECB FOLLOW THE FED?
}

\author{
ANSGAR BELKE \\ DANIEL GROS
}

\author{
CESIFO WORKING PAPER NO. 1428 \\ CATEgory 6: Monetary Policy And International FinanCE \\ MARCH 2005 \\ Presented at CESifo AREA CONFERENCE ON \\ Macro, MONEy AND InTERnATIONAL FinANCE, FEBrUARy 2005
}

\footnotetext{
An electronic version of the paper may be downloaded - from the SSRN website: http://SSRN.com/abstract $=688341$

- from the CESifo website: www.CESifo.de
} 


\title{
ASYMMETRIES IN THE TRANS-ATLANTIC MONETARY POLICY RELATIONSHIP: DOES THE ECB FOLLOW THE FED?
}

\begin{abstract}
The belief that the ECB follows the US Federal Reserve in setting its policy is so entrenched with market participants and commentators that the search for empirical support would seem to be a trivial task. However, this is not the case. We find that the ECB is indeed often influenced by the Fed, but the reverse is true at least as often if one considers longer sample periods. There is empirically little support for the proposition that there has been for a long time a systematic asymmetric leader-follower relationship between the ECB and the Fed. Only after September 2001 is there more evidence of such an asymmetry. We also find a clear-cut structural break between the pre-EMU and the EMU period in terms of the relationship between short term interest rates on both sides of the Atlantic.
\end{abstract}

JEL Code: E52, E58, F41.

Keywords: co-movement of interest rates, European Central Bank, Federal Reserve, monetary policy, policy coordination.

\author{
Ansgar Belke \\ University of Hohenheim \\ Department of Economics \\ Schloss, Museumsflügel 021 \\ 70593 Stuttgart \\ Germany \\ belke@uni-hohenheim.de
}

\author{
Daniel Gros \\ Centre for European Policy Studies \\ 1 Place du Congrès \\ 1000 Brussels \\ Belgium \\ Daniel.gros@ceps.be
}

We are grateful for valuable comments to Volbert Alexander, George M. von Fuerstenberg, Paul de Grauwe, Herbert Grubel, Carsten Hefeker, Christos C. Paraskevopoulos, Uwe Walz, and other participants in the following conferences: Asymmetries in Trade and Currency Arrangements in the 21st Century Conference, Deutsche Bundesbank, Frankfurt, CESifo Area Conference on Macro, Money and International Finance, International Economic Villa Mondragone Seminar, Tor Vergata/Rome, International Conference on Macroeconomic Analysis and International Finance, Rethymno/Crete, Ausschuss für Außenwirtschaftstheorie und politik im Verein für Socialpolitik, Graz, and the International Conference ,Die Rolle der erweiterten Europäischen Union“, Arbeitskreis Europäische Integration, Berlin. 


\section{Introduction}

In this paper we will address the question of whether the ECB has systematically followed the US Federal Reserve in setting interest rates. It is difficult to document "conventional wisdom" because it seems so obvious to everybody that few bother to actually provide evidence for it. One of the few instances in which it is possible to document the widespread expectation that the ECB follows the Fed is related in Garcia-Cervero 2002. In a Reuters poll of economists taken in November, 2002, the proportion of those expecting a cut by the ECB almost doubled (from 21 to $43 \%$ ) the day after the Fed did cut rates on November 5th. Later on, these analysts were proved to be wrong, but were they wrong at changing their mind in the first place?

While many seem to be convinced that the ECB does follow the Fed, few seem to ask the obvious question: What could be the rationale for the ECB to follow the Fed? The simplest explanation would be that moves by the Fed provide the ECB with an important signal (about the state of the US economy and financial markets). One implication of this explanation would be that the ECB should follow the Fed almost immediately because it would not have any reason to delay its move once the signal has been given. One could thus account for the episode related above (e.g., Begg et al. 2002, p. 42). The problem with this argument is that it implies that then the Fed should also follow the ECB because the euro area is of a similar size as the US economy. However, nobody seems to suggest that the Fed might also follow the ECB.

Another explanation might be that the US cycle precedes that of the euro area so that the ECB might appear to follow the Fed, but in reality it just reacts to the evolution of the euro area's cycle, which happens to lag that of the US. The problem with this explanation is that leads and lags in macroeconomic variables like output and employment are usually measured in months or quarters (Begg et al. (2002), pp. 41 ff., estimate the lag at 3-5 months), whereas the ECB is usually assumed to follow the Fed within a much shorter time frame. (See the example reported above.) Moreover, the business cycle effect should be accounted for by the autoregressive element that is present in standard causality tests. Finally, recent research clearly demonstrated that the impact of the US business cycle has become significantly weaker throughout the nineties as compared to the seventies and eighties. This is mainly due to the emergence of multinational firms which can afford to stick to longer-term strategies 
independent of business cycle troughs (Schroeder et al. 2002). Hence, this approach is not well-suited as an explanation for the "leader-follower" pattern.

Perhaps the most popular explanation why the ECB might follow the Fed is that the ECB is simply slow and inefficient. This explanation would roughly run as follows: The world's financial markets were buffeted over the last years by the emergence and then the bursting of an asset price bubble. The leadership of the Fed (Mr. Greenspan in particular) is simply smarter and was quicker to spot the problems. By contrast, so the story seems to go, the ECB is a new institution that still has to find its ways, and its decision making body is too large to come to quick decisions, especially given that it usually tries to forge a consensus before moving (Belke et al. 2002, Wyplosz 2001).

Another explanation could be grounded in a fundamental difference between the US and the euro zone economies: namely that the US economy is more flexible. This has important implications especially in times of heightened uncertainty. This can be seen most easily through the concept of the "option value of waiting". This concept formalises a common sense decision rule: if a decision involves some sunk costs, or any other element of irreversibility, it makes sense to postpone the decision until the uncertainty has been resolved. The temptation to postpone investment decisions is particularly strong when sunk costs are high and when the uncertainty is likely to be resolved in the near future. One can imagine in particular enterprises that have to consider normal investment projects, i.e. projects that would be slightly profitable under current circumstances and even more profitable in case the uncertainty is resolved in a positive sense, but would lead to losses if the uncertainty is resolved in a negative sense. In this case the enterprise would loose little (in terms of foregone profits) if it waited with the decision. Once the uncertainty has been resolved it would still have the option to proceed if the outcome is positive. ${ }^{1}$

The concept of the "option value of waiting" applies also to the ECB. If, during times of unusual uncertainty, it cuts rates today it risks having to reverse its decision soon. The ECB should thus cut today only if it is convinced that such a cut would make sense even if the uncertainty is resolved in a positive way. In this sense, monetary policy is not a game of "follow the leader", but of setting the right policy in the light of domestic inflation and growth prospects.

\footnotetext{
1 See Belke and Gros (2003). For a more formalized treatment of monetary policy effectiveness under uncertainty based on the real option approach see Belke and Goecke (2003).
} 
The models of decision-making under uncertainty also have a second implication. All decisions involve some transaction costs - whether they are about investment, or about hiring and firing. These last are especially important in Europe. This implies that businesses facing only a small change in prices may not respond immediately. There is always a band of inaction - a price range within which it does not pay to change course. The size of this band of inaction increases as uncertainty increases. And, given the structural rigidities in the euro zone economy, uncertainties probably affect decision-making in Europe more than they do in the US. As transactions costs (which are effectively sunk costs) are more important in Euroland than in the US it follows that for the ECB the option value of waiting for more information should be higher and might thus explain why the ECB is slower to react to signals than the Fed.

The problem with this explanation, however, is that it should hold only for periods when volatility is temporarily higher than usual because the option value argument is valid only if the uncertainty is resolved (diminished) after a certain period. The option value of waiting argument should thus apply only when financial markets are "excessively" turbulent. We find some evidence for this hypothesis in the sense that we find that it is mainly after September 2001 that the Fed seems to influence the ECB (and not vice versa).

The remainder of this paper applies a battery of quantitative and qualitative techniques to validate the hypothesis that the ECB systematically follows the US Federal Reserve. This hypothesis can also be put as a question: Does the probability of an interest rate move by the ECB increase after the Fed has moved (but not the other way round)? In other words, we check whether the behaviour of the analysts in the poll mentioned at the beginning can be backed up by a careful statistical analysis of the data. We proceed as follows: we first examine in chapter 2 some prima facie evidence and then proceed in chapter 3 to a more detailed econometric analysis using Granger causality methods and cointegration an weak exogeneity tests. To ensure robustness we use several different indicators and time periods and a variety of lag structures. In chapter 4 we then look closer at the EMU period and find that there is a clear structural break around September 2001. Chapter 5 concludes.

\section{ECB and Fed interest rate setting - First prima facie evidence}

A simple way to answer the question whether the ECB follows the Fed might be to look at the behaviour of the official rates set by the ECB and the Fed. However, these rates do not move frequently enough to allow the use of standard statistical methods without great caution. 
Hence one has to find indicators from financial markets, for example short term interest rates, which complement the analysis and make it more robust. Although central banks do not directly set the most widely watched indicator of short-term monetary conditions, namely the 1-month interest rate, they can nevertheless determine pretty much its evolution. If the ECB had systematically followed the evolution in the US (moves by the Fed as well as changes in US financial markets), one would expect to find that changes in US interest rates tend to lead changes in euro area short-term rates. At first sight this seems to have been the case if one looks at the short life span of the euro. Figure 1 plots the central bank (ECB_REFIN and FED_FUNDS) and the 1-month money market interest rate series (EURO_1M and USD_1M) for the euro zone and for the US since the start of EMU. We plot both levels and first differences. As expected, the 1-month rates closely move around to the central bank rates. Hence, we feel free to use money market rates to test whether the ECB follows the Fed.

This figure suggests at first sight that the US was leading the euro area by around one quarter both when interest rates were going up, from the trough in early 1999 and when they started falling in early 2001. Many observers concluded from this apparent relationship that the ECB mimicked the Fed in its monetary decisions. However, this popular belief was not corroborated by simple statistical analyses with data for monthly realisations of 3-month interest rates up to 2001 (Belke et al. 2002, Belke and Gros 2002a, Gros et al. 2002, pp. 45ff. and 62ff.). This early period was followed by a phase in which the Fed lowered its interest rate with an unprecedented speed while the ECB was more hesitant in this respect. The surprise cut by the Federal Reserve of 50bp on 3 January, 2001 is often cited as a telling example of the leader-follower relationship because after this move by the Federal Reserve the ECB found itself under increasing and incredibly strong pressure to cut its own rates as well. ${ }^{2}$ The last period which can be identified by visual inspection is characterized by the fact that the ECB follows the direction of the Fed steps but not by the same magnitude leading by mid-2001 to a positive gap in the interest rate levels between the euro zone and the US (in reversal of the development at the start of EMU). The sample period thus contains two periods with different interest rate differentials.

Interestingly enough these two periods of different interest differentials also broadly cover two different periods on the foreign exchange markets in the sense that until 2001 the euro declined from a temporary peak reached when EMU started, but this was then followed by a

\footnotetext{
${ }^{2}$ Wyplosz (2001), p. 1, reports clear anecdotic evidence of the demand by the markets, the media and even by Finance Ministers to cut rates during this period.
} 
period of dollar weakness. The period of dollar strength was associated with higher US interest rates and the period of dollar weakness was associated with lower US interest rates. This is what one would expect in general. But, as usual, it is difficult to disentangle cause and effect. Did changes in (policy) interest rates drive the exchange rate, or did exogenous shocks to the foreign exchange market affect the business cycle on both sides of the Atlantic and hence caused changes in interest rates? We do not want to be drawn in a discussion of this general issue and note just that if exchange rates movement were the exogenous factor one would expect a negative relationship between euro area and US interest rates: a weaker dollar should, ceteris paribus, make it more likely that the Federal Reserve will raise rates, whereas the ECB should become more inclined to cut rates. We did not observe any negative correlation of this kind in the data (whether on a contemporaneous or lagged basis).

Figure 1: Central bank rates and one-month interest rates in the euro zone and the US (January $1^{\text {st }} 1999$ to April $25^{\text {th }}$ 2003)

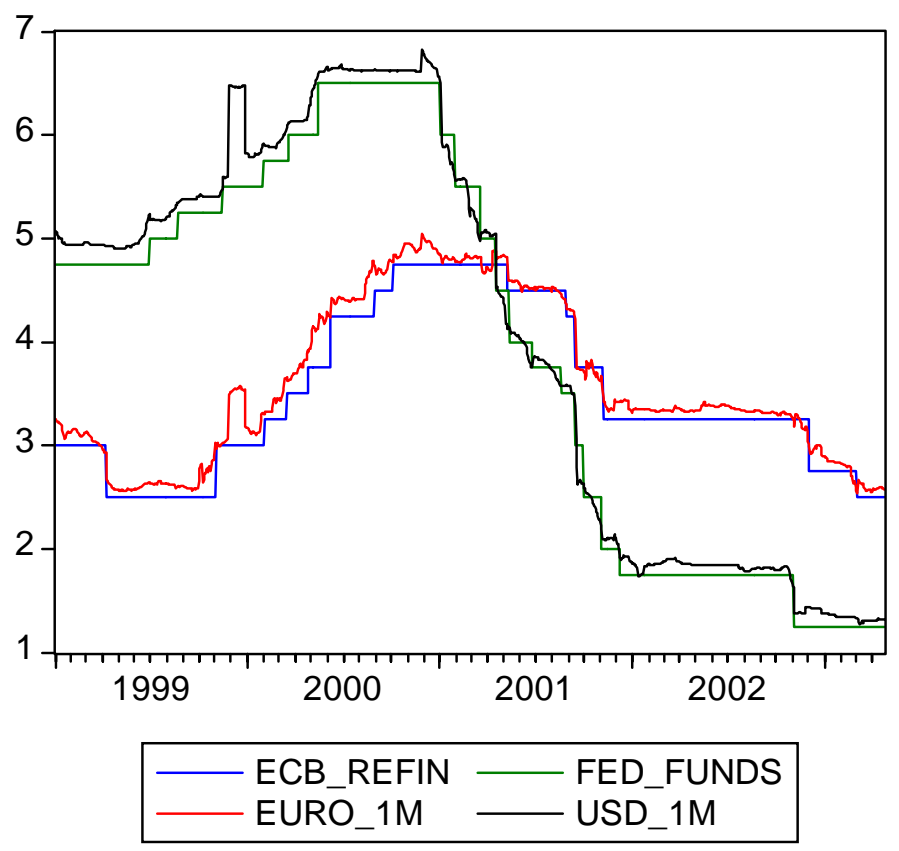




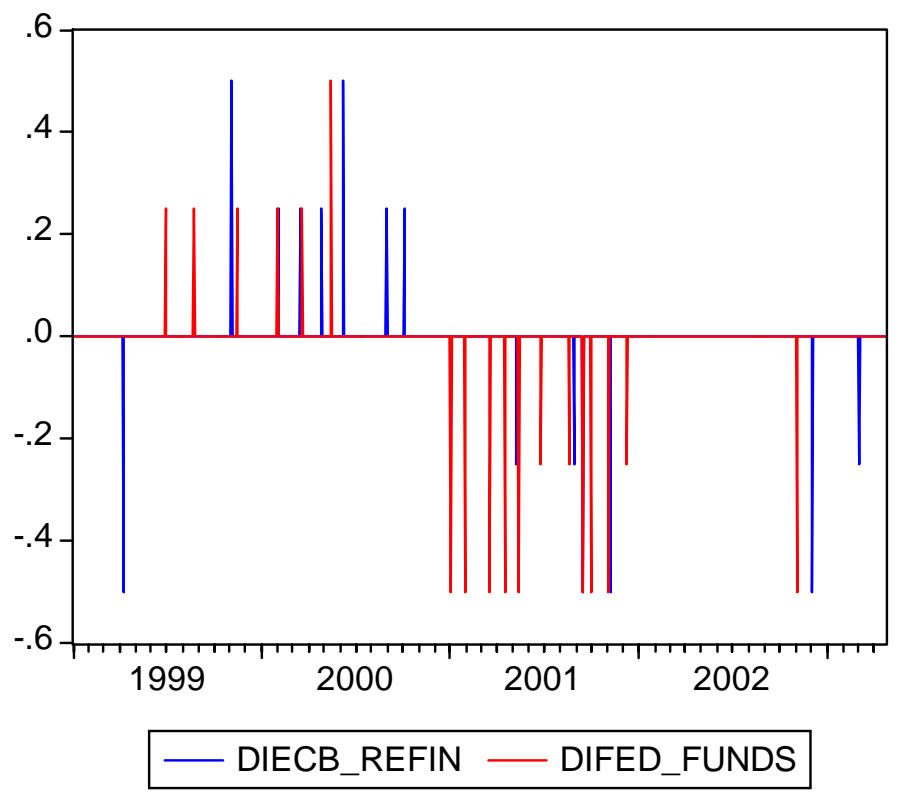

We complement the description of these stylized facts by a more institutional view of the monetary policy decision making process. In Table 1 we display a chronology of FED and ECB interest rates movements since 1999 by only referring to meeting dates where at least one of the central banks changed its rate. We assign a change of the interest rate to the day when it is agreed upon since we assume that it is priced into expectations from this day on. Note that the FED has always led the turning points in the interest rate cycle both in June 1999 and in January 2001. In order to address the relationship between interest rate movements among the two central banks we first need to consider how often they take interest rate decisions. Then we comment upon such decisions.

The ECB used to discuss monetary policy at each of its fortnightly meeting. Then on 8 November 2001, this was changed and the ECB decided to discuss monetary policy only once every four weeks (Perez-Quiros and Sicilia 2002, p. 8). This brought the ECB's rhythm closer to that of the FED, which meets every six weeks. If it were not for the possibility of intermeeting moves the one month rate should thus open a window of 2 weeks after a Fed meeting during which no change should be expected. But the FED has made three inter-meetings cuts while the ECB made only one in the aftermath of the terrorist attacks in the US. Indeed this constituted an extraordinary situation resulting in the only co-ordinated inter-meeting when the three central banks ECB, Fed and the Bank of England, cut by 50bp within 3 days. ${ }^{3}$

\footnotetext{
${ }^{3}$ The ECB has been criticised for making reactive, rather than proactive monetary policy decisions in the wake of September 11th. Perhaps, the ECB and other central banks would have waited longer before assessing the outcome of the terrorist strikes, and formulating and timing policy responses without the lead of the Fed.
} 
Table 1: Chronology of central bank rate changes by the Eurosystem and the Fed

\begin{tabular}{|c|c|c|c|c|}
\hline \multirow{2}{*}{ Date } & \multicolumn{2}{|c|}{ Level } & \multicolumn{2}{|c|}{ Change } \\
\hline & FED & ECB & FED & ECB \\
\hline 1-Jan-99 & & 3 & & 0 \\
\hline 8-Apr-99 & & 2.5 & & -50 \\
\hline 30-Jun-99 & 5.00 & & 25 & \\
\hline 24-Aug-99 & 5.25 & & 25 & \\
\hline 4-Nov-99 & & 3 & & 50 \\
\hline 16-Nov-99 & 5.50 & & 25 & \\
\hline 2-Feb-00 & 5.75 & & 25 & \\
\hline 3-Feb-00 & & 3.25 & & 25 \\
\hline 16-Mar-00 & & 3.5 & & 25 \\
\hline 21-Mar-00 & 6.00 & & 25 & \\
\hline 27-Apr-00 & & 3.75 & & 25 \\
\hline 16-May-00 & 6.50 & & 50 & \\
\hline 8-Jun-00 & & 4.25 & & 50 \\
\hline 31-Aug-00 & & 4.5 & & 25 \\
\hline 5-Oct-00 & & 4.75 & & 25 \\
\hline 3-Jan-01 & 6.00 & & -50 & \\
\hline 31-Jan-01 & 5.50 & & -50 & \\
\hline 20-Mar-01 & 5.00 & & -50 & \\
\hline 18-Apr-01 & 4.50 & & -50 & \\
\hline 10-May-01 & & 4.5 & & -25 \\
\hline 14-May-01 & 4.00 & & -50 & \\
\hline 27-Jun-01 & 3.75 & & -25 & \\
\hline 21-Aug-01 & 3.50 & & -25 & \\
\hline 30-Aug-01 & & 4.25 & & -25 \\
\hline 17-Sep-01 & 3.00 & 3.75 & -50 & -50 \\
\hline 2-Oct-01 & 2.50 & & -50 & \\
\hline 6-Nov-01 & 2.00 & & -50 & \\
\hline 8-Nov-01 & & 3.25 & & -50 \\
\hline 11-Dec-01 & 1.75 & & -25 & \\
\hline 6-Nov-02 & 1.25 & & -50 & \\
\hline 5-Dec-02 & & 2.75 & & -50 \\
\hline 6-Mar-03 & & 2.5 & & -25 \\
\hline
\end{tabular}

Note: For the US, the Fed funds rate (http://www.federalreserve.gov/fomc/fundsrate.htm2), and for the euro zone the ECB refi rate (http://www.ecb.int/index.html) is tabulated.

There are two further instances (in January 2001, the first easing of the cycle and in November 2001) when the FED made inter-meetings cuts not triggered by extraordinary events. The ECB does not seem to have this "urgency" to react to economic information. However, the Fed and the ECB have moved within a week on four occasions (apart from the

However, the decision by the ECB to follow the Fed's lead represents a shift to a more pre-emptive policy stance. In cutting interest rates without a clear indication of the likely economic impact of events in the US and the impact on oil prices, the ECB took a risk that cheaper money in Euroland may induce greater price pressures over the medium term that could threaten its $2 \%$ inflation target. However, according to our option value- 
inter-meeting cuts in September 2001) in February 2000, in May 2001 and finally in November 2001. Hence, we could tentatively conclude that the FED leads the ECB. ${ }^{4}$ Note however, that the FED could be leading the ECB due to pure "cyclical" considerations (international transmission of the cycle). It is a well-known fact that the business cycle in the US has led Euroland's in the period under consideration by about 1-2 quarters and thus it makes perfect sense that the FED is the first one to change direction on interest rates movements. ${ }^{5}$ A statement of an influential member of the ECB Board, Issing, on BBC News one day after the Fed's quarter-point cut of interest rates on June $27^{\text {th }}, 2001$, is illuminating in this respect. Asked whether the ECB would follow the Fed's lead, he said: "The Fed did what was necessary for the US and we will do what is necessary for Europe"6. This statement would suggest that any leader-follower relationship would purely accidental. It has to seen, however, in the context of the 'objective functions' or mandates of the two institutions. It is widely perceived that the Federal Reserve pays relatively more attention to growth than the ECB. This is another piece of perceived wisdom that is hard to document since estimates of standard Taylor rule functions fit both the US and the euro area data and the estimates do not yield significant differences in the relative weights attached to inflation and the output gap. We not want to take a stance on this issue, but it is clear that if the hypothesis that the ECB pays more attention to inflation were true one would expect the ECB to be more cautious in following the Fed during an easing cycle.

But the key question we want to address is rather whether, even without any news on the evolution of the euro area economy, a FED decision to cut rates increases the probability of a cut by the ECB (see for instance the Reuters poll mentioned in the introduction). With our high frequency data (daily and weekly) we can differentiate between time lags caused by different positions along the economic cycle from those which are related to other issues (e.g. the alleged inability of the ECB to react quickly to financial market developments because of the need to reach a consensus in the Governing Council).

If the leader-follower relationship were purely a function of the business cycle lag one would expect that ECB to follow the Fed with a corresponding lag, i.e. 3-6 months later. If the ECB were just slower to react to financial market shocks one would expect it to be able reach a

argument (Gros and Belke 2003), the ECB was correct in its assessment of the risks to EU growth, and the decision to cut its interest rate has contributed to enhancing the ECB's credibility as a global monetary authority.

${ }^{4}$ In the spring of 1999, the ECB somewhat belatedly reacted to fears of deflation triggered by the LTCM crisis as another exceptional event in our sample.

${ }^{5}$ Begg et al. (2002, p. 42) and Breuss (2002, p. 13) see a time lag between Fed and ECB interest rate decisions. They attribute the reason for the Fed's moving first to the US cycle leading the euro zone's. 
new consensus in its Governing Council about 1 or two meetings after the Fed (where there is only one decision maker who counts: Chairman Greenspan), implying a lag of about 1-2 months. Finally, in the crude perception of financial markets that the ECB just does not know what to do and just follows immediately the Fed on would expect a lag of less than a month in terms of policy rates, which should translate in a (partial) immediate reaction in the one months rates used by us.

The procedure used in this paper to ascertain the existence of a leader-follower relationship essentially is a Granger-causality (GC) test procedure. These tests can show whether past values of a certain variable (e.g. US interest rates) influence another variable (e.g. euro interest rates) after one has taken into account the patterns that might link the second variable (euro rates) to its own past. If this is not the case, we speak of Granger non-causality (Greene 2003, pp. 590ff.). However, Granger causality measures precedence and information content but does not by itself indicate causality in the more common use of the term.

A battery of statistical tests is run covering the entire sample period (1989 to 2003) to test the leader-follower hypothesis also for the Bundesbank and the Fed as well as only the euro period. The latter period is even split further into sub-samples to test for robustness of our results. ${ }^{7}$. Overall, this gave the result that US interest rates do not influence euro interest rates in the sense of a one-way causation. The US interest rate of the previous time periods did not have a statistically significant one-way influence on the current euro interest rate when all other factors were taken into account. This suggests that the visual impression of a US leadership over the entire period might be misleading for most of the periods analysed by us.

\section{Empirical analysis}

The first section of this chapter will outline our statistical approach in more detail. As explained in the first chapter, the administratively set central bank interest rates as well as the 1-month money market rates of the US and the euro area were used as both rates are widely watched indicators of the monetary policy stance. In order to cope with the relatively short sample available for the EMU period we also include up to 9 years before the start of EMU in our analysis, implicitly testing the validity of the leader-follower hypothesis for the ECB's predecessor, the German Bundesbank, as well. We clearly separate between the Deutsche Mark era and the euro era in our empirical analysis. Our prior was that the results should not

\footnotetext{
${ }^{6}$ See BBC-News (2001).

${ }^{7} \mathrm{We}$ used first differences, i.e. changes in interest rates, when the level series seemed to contain a unit root.
} 
be very different between these two sub-periods, the reason being that the goal in monetary policy was almost the same for the Bundesbank than it is for the ECB. However, as will become clear below our prior was not at all confirmed.

The data for the central bank rates, the targeted federal funds rate (funds rate) and the ECB interest rate for main refinancing operations (refi rate), comprise the sample 1999 to 2003, and are taken from the homepages of the European Central Bank and the Federal Reserve (http://www.ecb.int/index.html, http://www.federalreserve.gov/fomc/fundsrate.htm). The data for the weekly and daily realisations of the 1-month LIBOR euro and dollar interest rates are taken from Datastream Primark. Our pre-EMU rates are synthetic euro rates. We have used the following samples: for central bank rates: January $1^{\text {st }} 1999$ to April $25^{\text {th }} 2003$, for weekly realisations of 1-month rates: from January $6^{\text {th }}, 1989$, to April $25^{\text {th }} 2003$, for daily realisations of 1-month rates: May $8^{\text {th }} 1989$ to May $8^{\text {th }} 2003 .^{8}$

\subsection{Preliminaries}

The first step in the empirical work concerned the choice of the statistical procedure. The simplest available procedure was chosen to ascertain the existence of a leader-follower relationship, i.e., the so-called Granger-causality tests (and related approaches). In order to make sure that our results do not depend on the particular test period chosen, we ran a battery of statistical tests for a number of periods, e.g. covering the entire euro period (1999 until 2003) and different periods from the end of 1989 onwards. What are the appropriate interest rates in our context? Optimally, we should investigate the instrument of the central bank for monetary policy. Both the ECB and the Fed operate in the money market, but at slightly different maturities. They cannot influence longer term interest rates directly (Borio 2001), their direct influence is limited to the overnight money market rate in the case of the US and the rate for fortnightly operations in the case of the ECB. ${ }^{9}$ The monthly rates we use are of course, influenced by the expectations about the future path of the shorter rates controlled by the central banks. ${ }^{10}$

\footnotetext{
${ }^{8}$ Daily data refer to working days only. Weekends and holidays were eliminated.

${ }^{9}$ The ECB also provides some funds at longer maturities (three months).

${ }^{10}$ See Ulrich 2003, p. 7, and Wyplosz 2001, pp. 6f. Perez-Quiros and Sicilia (2002), pp. 7ff., argue that policy announcements made on Council meetings should not trigger any reaction of asset prices in case of full predictability, since market participants have already correctly anticipated these policy decisions on the day when the central bank rate is changed. However, in a world of uncertainty, collective decisions on monetary policy and lack of transparency, effective communication and active guidance to the markets, predictability and the anticipation of the exact timing of interest rate changes might not be fully attainable. This justifies the use of the refi and the targeted funds rate in our case.
} 
A priori, if one uses market interest rate data, it becomes inherently difficult to distinguish policy maker's intentions from demand disturbances in financial markets (Bergin and Jordá 2002, p. 2). However, Figure 1 has clearly shown that central bank rates and market rates move closely together. Moreover, using market rates has the advantage that one captures, even if imperfectly, probabilities of future moves of the central bank rates. If one uses only the latter one has only the realisations, not the expectations, which determine market rates which are in turn the rates that influence the economy.

For these reasons we decided to define the interest rate variables as follows:

1. daily realisations of Central bank rates (targeted Fed funds rate and ECB refi rate),

2. weekly realisations of 1-month money market rates, and

3. daily realisations of 1-month money market rates.

Ad 1: The Federal Reserve announces an objective for the federal funds rate, the federal funds target. Hence, it makes sense to use the latter variable as the operating target in our estimations. Hamilton and Jordá (2000) argue that the target data for the federal funds rate accurately reflect the monetary policy stance since they reflect policy considerations instead of demand innovations. ECB decisions concern the setting of the main refinancing operations. So the operating target is the refi rate. With an eye on their impact on the markets, we feel legitimized to include changes in the central bank rates starting with the day of the meeting they were decided upon, i.e. in some cases earlier than their date of de-facto effectiveness. ${ }^{11}$

Ad 2: We preferred 1-month rates to 3-month rates (as used in Belke and Gros 2002a and Gros et al. 2002) because it is rather difficult to measure reaction lags of less than 3 months based on 3-month rates. With daily rates we have the maximum of information, but most news on a daily basis come presumably from financial markets. We used LIBOR rates because they are highly comparable since they refer to the same market and to the same time zone, etc.

Ad 3: Here we also used LIBOR rates, but weekly realisations to eliminate (at the price of a smaller sample) some of the noise that might come from short term disturbances in money markets. With weekly realisations the average number of observations available to detect a leader-follower pattern would be 1-2 if the ECB had followed the Fed tightly.

\footnotetext{
11 For instance, the Governing council of the ECB decided to lower the minimum bid rate on the main refinancing operations by 0.25 percentage points to $2.50 \%$, starting from the operation to be settled on March $12^{\text {th }}, 2003$. In this case, we assigned the change already to March $6^{\text {th }}, 2003$.
} 
Before the regressions were run, however, an important empirical caveat had to be taken into account. Since the level series seem to contain a unit root ${ }^{12}$ and Granger causality tests tend to give misleading results if the variables considered contain unit roots, it was first tested whether the interest rates were actually stationary during the time period considered. The results of the unit root tests are available on request and suggest that the series have to be differenced once (to get the change in interest rates between two periods) in order to make them stationary.

\subsection{Granger causality?}

The next step was to use Granger-causality (GC) analysis to establish whether there is a follower-leader relationship between the changes in the relevant Euro and US interest rates. We conduct separate GC analyses for all of the relevant variables.

First, we used central bank rates. In order to test for the existence of some policy link between the FED decisions on the one hand and the ECB on the other, we perform Granger causality tests among the two intervention rates. This means that we are dealing with daily observations of series that move with discrete jumps (the refi rate for the ECB and the fund rate for the FED). This is somewhat of an extreme exercise because this sort of test is designed for smooth variables instead of variables that jump from one value to another. Note, however, that targets are typically modified in discrete increments rather than continuously. Hence, the very nature of what we want to capture is discrete and represents a structural break in the series. Moreover, the changes in targets are spaced irregularly in time (Hamilton and Jordá 2000). We could argue that by using this dataset we are forcing the series to maximise its co-movements. If we do not find empirical evidence with this data set, it is doubtful that we would find it either with a more "conventional" dataset. The smoother the series (take for instance the monthly 3-month LIBOR money market rates we used in Belke and Gros 2002a and Gros et al. 2002) the more difficult to capture any reaction to abrupt rates changes and the more contaminated this series would be with irrelevant information (Garcia-Cervero 2002).

Second, we compromised on 1-month market rates with an eye on Figure 1 which clearly demonstrates that the time pattern of the latter is not too different from that of the central bank rates. Hence, we conducted Granger causality tests for weekly realisations of 1-month money market rates and daily realisations of 1-month money market rates.

The main results of the Granger-causality tests are tabulated below in Figures 2 to 4 and

\footnotetext{
${ }^{12}$ The level series does not fluctuate around a constant mean and its variance is not constant and finite.
} 
Tables 3 and 4. We have used the same samples like in our unit root tests to run GC tests. However, we decided to use different numbers of lags. Note that the daily data refer to weekdays and thus a month is about 21 observations rather than 30 . In order to limit the loss of degrees of freedom (and limit the analysis to a time span that does not exceed the reaction lag of even the slowest central bank), we do not test for more than 5 months of history (about 110 working days), and, for simplicity, report results only at the standard 5\% significance level.

One should also be well aware that the results often depend greatly on the lag structure. For central bank rates we used lags from 1 to 110 , for weekly realisations of the 1-month rates we applied 1, 2, 3, 4, 9 and 13 ("since interest rate decisions are often met closely to each other a lower lag is more probable") and for daily realisations of these rates 1, 5 (one week), 10, 21, 42 ( 2 months). This procedure enabled us to take into account that the periodicity of the lag is not a priori fixed by theory. For robustness reasons and with an eye on our hypothesis of a possible break in the relation around the start of EMU (and the turn of the year 2000-01), different sample periods were used in a fashion coherent with our unit root tests. By investigating (a) the whole sample of available data from the end of the eighties on until "today", (b) the limited sample from the end of the eighties on until the end of 1998 and (c) the sample consisting of the EMU period, we clearly separate between the deutsche mark era and the euro era in our empirical analysis. Our prior is that the results should not be so much affected - the reason being that the goal in monetary policy was almost the same for the Deutsche Bundesbank than it is for the ECB. However, the behaviour of the Bundesbank might have also been influenced by the anticipation of EMU. We will discuss this issue later on by asking whether the ECB systematically follows the US Federal Reserve to a larger or smaller extent than the Bundesbank.

The whole range of GC results for levels and first differences of the central bank rates and first differences of the market rates is summarized below. In some cases, we plot the sequence of probability values dependent on the lag structure jointly with the 5 percent significance level as illustrative examples. We regard the hypothesis that the ECB followed the Fed as a one-way causality which is corroborated exactly if the p-values are below 5 percent for the GC test with the null hypothesis "The US rate does not GC the euro rate", but at the same time the p-values are above 5 percent for the GC test with the null hypothesis "The euro rate does not GC the US rate". 
Figure 2: Results of Granger causality tests (P-values dependent on lag-length)

a) For central bank rates (daily realisations, in levels)
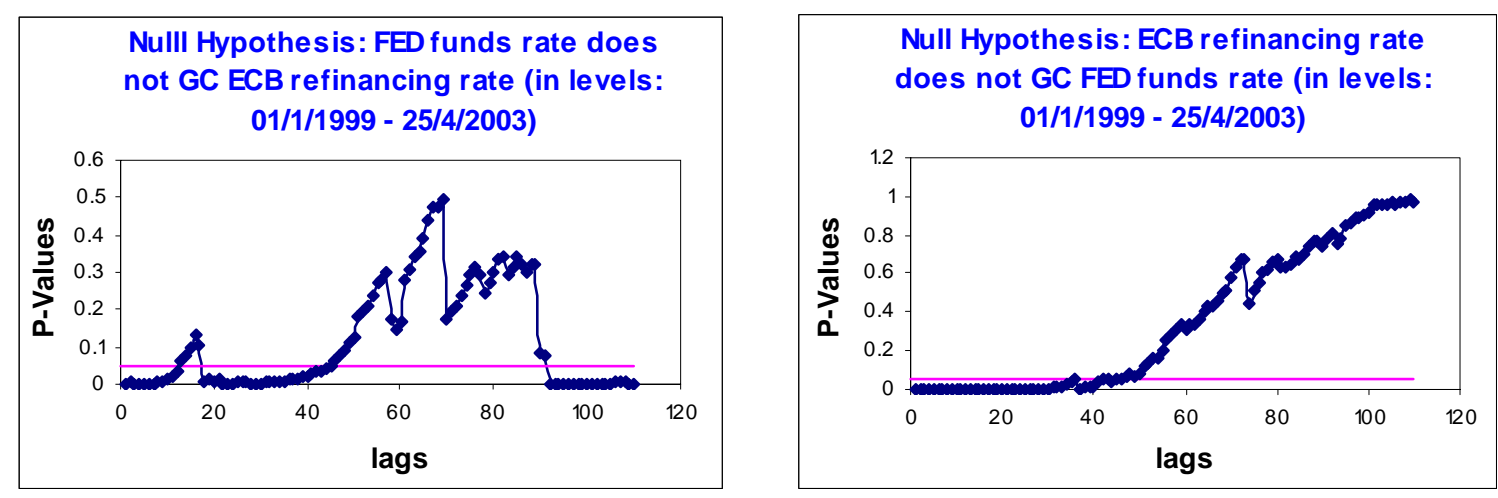

b) For central bank rates (daily realisations, in differences)
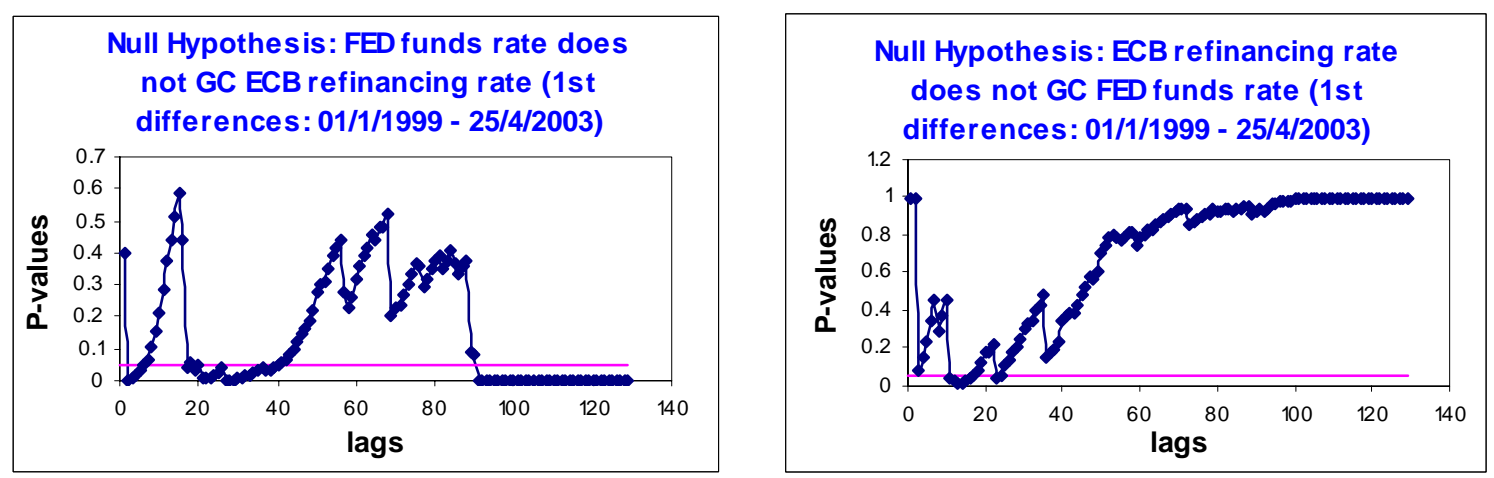

Figure 3: P-values for Granger Causality tests of weekly realisations of the 1-month LIBOR rates
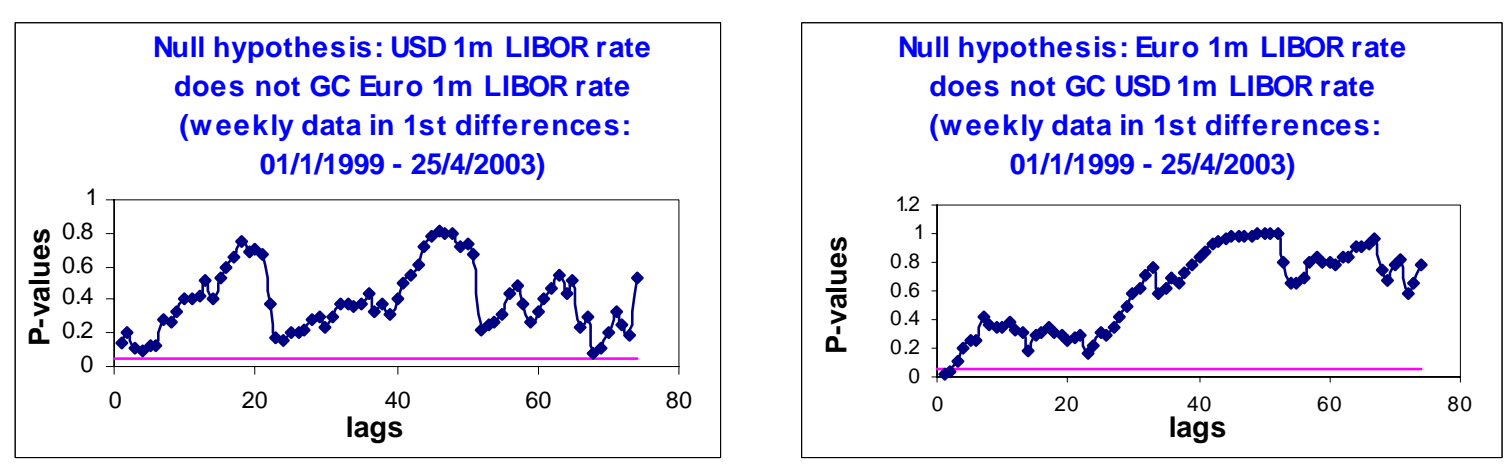
Figure 4: P-values for Granger Causality tests of daily realisations of the 1-month LIBOR rates
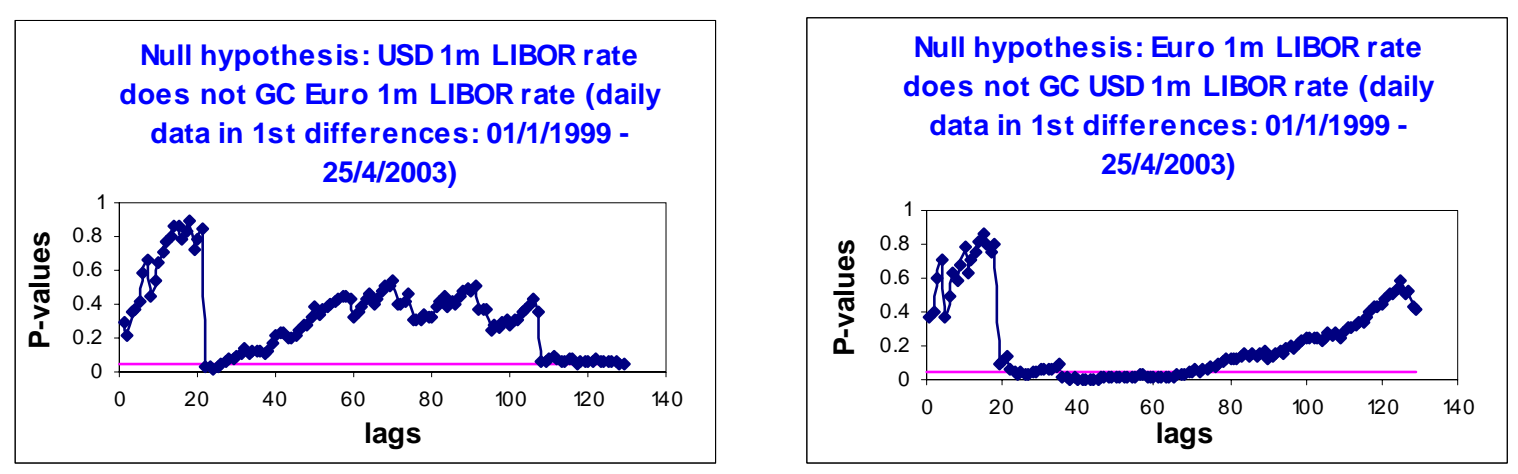

Table 2: Results of Granger causality tests by sample period and lag length (first differences of weekly realisations of the 1-month LIBOR rates)

\begin{tabular}{|l|l|l|l|l|l|l|}
\hline \multirow{2}{*}{$\begin{array}{l}\text { Lag length } \\
\text { in weeks }\end{array}$} & \multicolumn{2}{|l|}{ Full sample: 1989-2003 } & \multicolumn{2}{l|}{ Pre-EMU: 1989-1998 } & \multicolumn{2}{l|}{ EMU: 1999-2003 } \\
\cline { 2 - 7 } & $\begin{array}{l}\text { US does not } \\
\text { GC EU }\end{array}$ & $\begin{array}{l}\text { EU does not } \\
\text { GC US }\end{array}$ & $\begin{array}{l}\text { US does not } \\
\text { GC EU }\end{array}$ & $\begin{array}{l}\text { EU does not } \\
\text { GC US }\end{array}$ & $\begin{array}{l}\text { US does not } \\
\text { GC EU }\end{array}$ & $\begin{array}{l}\text { EU does not } \\
\text { GC US }\end{array}$ \\
\hline 1 & - & - & - & - & - & 0.011 \\
\hline 2 & - & - & - & - & - & 0.045 \\
\hline 3 & - & - & - & - & - & - \\
\hline 4 & - & - & - & - & - & - \\
\hline 9 & - & 0.008 & - & 0.000 & - & - \\
\hline 13 & - & 0.022 & - & 0.002 & - & - \\
\hline
\end{tabular}

Note: Full sample: 06/01/89 - 25/4/2003, pre-EMU period: 06/01/89 - 25/12/1998, EMU period: 01/1/1999 - 25/4/2003. 
Table 3: Results of Granger causality tests by sample period and lag length (first differences of daily realisations of the 1-month LIBOR rates)

\begin{tabular}{|l|l|l|l|l|l|l|}
\hline \multirow{2}{*}{$\begin{array}{l}\text { Lag length } \\
\text { in working } \\
\text { days }\end{array}$} & \multicolumn{2}{|l|}{ Full sample: 1989-2003 } & \multicolumn{3}{l|}{ Pre-EMU: 1989-1998 } & \multicolumn{2}{l|}{ EMU: 1999-2003 } \\
\cline { 2 - 7 } & $\begin{array}{l}\text { US does not } \\
\text { GC EU }\end{array}$ & $\begin{array}{l}\text { EU does not } \\
\text { GC US }\end{array}$ & $\begin{array}{l}\text { US does not } \\
\text { GC EU }\end{array}$ & $\begin{array}{l}\text { EU does not } \\
\text { GC US }\end{array}$ & $\begin{array}{l}\text { US does not } \\
\text { GC EU }\end{array}$ & $\begin{array}{l}\text { EU does not } \\
\text { GC US }\end{array}$ \\
\hline 1 & - & 0.021 & - & 0.015 & - & - \\
\hline 5 & - & 0.004 & - & 0.008 & - & - \\
\hline 10 & 0.008 & 0.001 & 0.005 & 0.001 & - & - \\
\hline 21 & 0.001 & 0.000 & 0.002 & 0.001 & - & - \\
\hline 42 & 0.000 & 0.000 & 0.000 & 0.000 & - & 0.004 \\
\hline
\end{tabular}

Note: Full sample: 08/05/89 - 08/05/2003, pre-EMU period: 08/05/89 - 31/12/1998, EMU period: 01/1/1999 - 08/05/2003.

Ad 1: Results for central bank rates: In a first step, we summarise the results of the GC analysis for the levels of the central bank rates. There is strong and consistent evidence that the FED GC (Granger-causes) the ECB, when we limit the analysis to lags up to around 40 days. The relationship holds at virtually all-relevant lags within this sample (left graph of Figure 2a). Interestingly there is also evidence that at the same time the ECB Granger causes the Fed (right graph of Figure 2a); but this unwinds as soon as we extend the study to more than 40 working days lags (possibly due to the few breaks). When we extend the number of lags to lags of at least around 90 working days (about 4.5 months) we find again evidence that the FED GC the ECB; this time the relation again holds for all relevant lags. At the same time the hypothesis that the Fed does not follow the ECB cannot be rejected at the usual significance level of 5 percent. Hence, we find evidence that the ECB follows the Fed in a one-way direction. However, this holds only with long lags. We interpret this as evidence in favour of relevance of cyclical considerations instead of policy interaction. However, given the special time series behaviour of the official central bank rates we do not put a lot of weight on these results.

As a second step and as a complementary check, we performed an additional exercise to see whether the main results still hold, this time with the first differences of the central bank interest rates rather than interest rates levels. Note that now we test whether daily changes in 
the fund rate GC daily changes in the ECB refinancing rate. The risk is that, due to the high proportion of zeros (since rates do not often change on a daily basis) results get distorted, especially if we include few lags. In order to minimise this risk we include as many lags as needed so as to guarantee at least one observation different from zero in the history of each variable. Here, we need about 20 working days of history in order to find evidence that the FED GC the ECB, which holds from 20 to 40 and from 90 to more than 120 daily lags and disappears in between. We cannot find any GC running between the Fed and the ECB for short lags (10 to 15 day lags), but for these lags there is evidence that the FED GC the ECB. For extremely short lags, the Fed seems to impact the ECB in a one-way direction. Hence, it is seems to be possible to find some causality, but we again would warn against putting too much emphasis on these results.

Ad 2: Results for weekly realisations of the 1-month rates: In Table 2, a surprising pattern emerges. At the usual 0.05 significance level there is no case in which we have to reject the null hypothesis that the US does not influence the euro area. But we also find that in six out of the 18 cases considered we have to reject the hypothesis that the euro area interest rates do not influence US rates. This is the case for short lags (1-2 weeks) during the EMU period and for longer lags ( 9 or 13 weeks) for both the full sample and the Pre-EMU period.

Ad 3: Results for daily realisations of the 1-month rates: The evidence in Table 3 is less one sided against the hypothesis that the ECB follows the Fed. In six cases we find evidence that the Fed Granger causes the ECB. However, in all of these cases it is also found at the same time that the US rate is simultaneously determined by the euro interest rate. Hence this cannot be interpreted as evidence for a leader-follower relationship either. ${ }^{13}$ As for the weekly data, however, we find several (in this case 5) cases in which one has to reject decisively the hypothesis that the ECB does not influence the Fed (or more precisely that euro area (preEMU: DM or synthetic euro) interest rates do not influence dollar rates).

Do the results deliver an answer to the question whether the Euro area systematically followed the US Federal Reserve? When we look at Tables 3 and 4 we would be tempted to turn the question around: has the Fed systematically followed Euro area developments? And has the euro area influence on the Fed been stronger or weaker before EMU? While great

\footnotetext{
${ }^{13}$ Overall, our new results confirm those contained in the studies by Belke and Gros (2002a) and Gros et al. (2000) which were based on an investigation of monthly realisations of the 3-month LIBOR interest rates and a smaller sample: In no case does one have to reject the null hypothesis that the US interest rate does not 'Granger cause' the euro interest rate and at the same time not reject the null hypothesis that the euro interest rate does not Granger cause the US rate.
} 
caution must exercised in interpreting these results with fixed lag lengths it is clear that they do not give any support to the null hypothesis that the ECB follows in an asymmetric way the Fed (nor seems the Bundesbank have done this during the pre-EMU period). If we limit our analysis to the euro period, the hypothesis of the Fed being a follower dominates clearly that of the US being the leader and the euro zone being the follower.

We regard these results with some caution because we are - at least with respect to the correct treatment of the central bank interest rate series - on the "frontier" of standard time series analysis. We are not surprised that we find a strong structural break between the pre- and post-EMU period. While the ECB has taken over most of the trappings of the Bundesbank (emphasis on price stability, use of monetary indicator, etc.) its behaviour should be different because it is responsible for a much larger and somewhat less open economy (Belke and Gros 2002). Moreover, our pre-EMU rates are synthetic euro rates. Hence they contain over $40 \%$ DEM rates (plus satellites like NL and AUS), but also LIT and FF rates, which at times diverged from DEM rates. While it is generally assumed that the DEM dominated the other currencies, there has been some discussion to what extent the Deutsche Bundesbank did really dominate the EMS. For instance, Fratianni and von Hagen (1990) found that Germany had a limited leadership role among European countries before the start of EMU. Hence it is not surprising that we find a clear cut structural break between the pre-EMU and the EMU period in terms of the relationship between short-term interest rates.

\subsection{Testing for cointegration and for weak exogeneity of the US interest rate}

In this section, we address two questions within the Johansen-framework of a cointegrating VAR analysis (Johansen 1991, 1995). Is there a stochastic co-movement between the US and the euro interest rate? And: If there is a co-movement, is it driven by the US interest rate? Hence, we check for cointegration between the US and the euro interest rates and for weak exogeneity of the US interest rate in the cointegrating VAR before we move to further conclusions. In the preceding chapter, we argued that due to the non-stationary character of the time series, we had to conduct our GC analysis in first differences for the 1-month LIBOR rates. This clearly need not be the case if the US and the euro zone time series are cointegrated. In this case, we can additionally use level information in order to identify the nature of the relationship of the two series in the data-generating process.

The results of the cointegration tests between the US and the euro zone interest rates are displayed in Tables 4 and 5 below. Due to their administrative nature we refrain from a 
cointegration analysis of the time series for central bank rate time series. Hence, we only analyse the weekly and daily realisations of the 1-month LIBOR rates. If we could reject the null hypothesis of no cointegration vector on the 5 percent level based both on the Johansen "Maximum eigenvalue" and the "Trace test", we denote this - if not indicated otherwise - with a 'yes' in column 2 of Tables 4 and $5 .{ }^{14}$ In addition, we test for weak exogeneity of the US interest rate by using an LR test of binding restrictions within the Johansen cointegration test framework (Greene 2003, p. 192f.). Conditional on the existence of only one cointegrating relation, the LR test does not reject our imposed binding restriction of weak exogeneity if the realisation of the $p$-value of the LR test statistics is above conventional values. The relevant $p$ value is tabulated in Tables 4 and 5, column 4.

According to Hendry (1993), the hypothesis of weak exogeneity cannot be rejected for these regressors if they can be characterised as a pure random walk independent of the stationary cointegration/error-correction term EC(-1). Hence, we restrict the coefficient of EC(-1) to be zero in the ECM representation of the US interest rate and test for the significance of this restriction. Weak exogeneity is already well-known as a necessary condition for an asymptotically efficient estimation of an ECM. An empirical test of this additional exogeneity premise becomes necessary since the ECM we have in mind if the ECB (Bundesbank) really followed the Fed represents a restricted model in the sense that it is regarded as an 'autonomous' relation, i.e. it is restricted to one single dependent variable, namely the change in the Euro interest rate. If the hypothesis of weak exogeneity cannot be rejected, the estimation of a fully defined dynamically interdependent system of equations can be avoided. At the same time, estimation can be conducted with more degrees of freedom. Weak exogeneity guarantees that the parameters of the ECM can be estimated without loss of information on the basis of the so-called conditional distribution (Banerjee et al. 1993, p. 18, Fischer, Peytrignet 1991, p. 483). This ECM is often called a conditional model, since a oneway causation from the regressors like for instance the US interest rate to the endogenous variable euro zone interest rate is assumed. While a test of weak exogeneity represents by itself a necessary step towards the estimation of an ECM, it is of even more use in our context. If the U.S. interest rate could be characterized as weakly exogenous the direction of the causation would be identified as running from the U.S. to the euro zone. Let us now

\footnotetext{
${ }^{14}$ In our cointegration tests we allow for a deterministic trend in the data, i.e. an intercept (and no trend) in the cointegrating equation and in the test VAR. Additional tests assuming that the levels of the interest rates do not have deterministic trends (as is often supposed for interest rates) showed that the results do not change much. However, since the trend is important as a sample property and the relevant interest rates revealed a certain trend within the chosen sample (see Figure 1) we do not display these results here.
} 
display the results of the cointegration and the weak exogeneity tests (Tables 4 and 5).

Table 4: Tests for cointegration and for weak exogeneity (for weekly realisations of the 1-month LIBOR rates)

\begin{tabular}{|c|c|c|c|c|c|c|}
\hline \multirow{2}{*}{$\begin{array}{l}\text { Lag } \\
\text { length in } \\
\text { weeks }\end{array}$} & \multicolumn{2}{|c|}{ Full sample: 89-2003 } & \multicolumn{2}{|c|}{ Pre-EMU 89-98 } & \multicolumn{2}{|c|}{ EMU 99-2003 } \\
\hline & $\begin{array}{l}\text { Cointegration } \\
\text { IUS IEU (yes or } \\
\text { no, at } 5 \% \text { level, } \\
\text { trace and max- } \\
\text { eigenvalue test) }\end{array}$ & $\begin{array}{l}\text { Weak } \\
\text { exogeneity of } \\
\text { IUS } \\
\text { (yes or no)* }\end{array}$ & $\begin{array}{l}\text { Cointegration } \\
\text { IUS IEU (yes or } \\
\text { no, at } 5 \% \text { level, } \\
\text { trace and max- } \\
\text { eigenvalue test) }\end{array}$ & $\begin{array}{l}\text { Weak } \\
\text { exogeneity of } \\
\text { IUS } \\
\text { (yes or no)* }\end{array}$ & $\begin{array}{l}\text { Cointegration } \\
\text { IUS IEU (yes or } \\
\text { no, at } 5 \% \text { level, } \\
\text { trace and max- } \\
\text { eigenvalue test) }\end{array}$ & $\begin{array}{l}\text { Weak } \\
\text { exogeneity of } \\
\text { IUS } \\
\text { (yes or no)* }\end{array}$ \\
\hline 1 & no & yes $(0.81)$ & no & no $(0.01)$ & $\begin{array}{l}\text { no (none of the } \\
\text { series with a } \\
\text { unit root, } \\
\text { stationary VAR } \\
\text { in levels) }\end{array}$ & no $(0.01)$ \\
\hline 2 & no & yes $(0.97)$ & no & no $(0.01)$ & $\begin{array}{l}\text { no (none of the } \\
\text { series with a } \\
\text { unit root, } \\
\text { stationary VAR } \\
\text { in levels) }\end{array}$ & no $(0.00)$ \\
\hline 3 & no & yes $(0.78)$ & no & no $(0.02)$ & $\begin{array}{l}\text { no (none of the } \\
\text { series with a } \\
\text { unit root, } \\
\text { stationary VAR } \\
\text { in levels) }\end{array}$ & no $(0.00)$ \\
\hline 4 & no & yes $(0.83)$ & no & no $(0.03)$ & $\begin{array}{l}\text { no (none of the } \\
\text { series with a } \\
\text { unit root, } \\
\text { stationary VAR } \\
\text { in levels) }\end{array}$ & no $(0.00)$ \\
\hline 9 & no & yes $(0.56)$ & yes & no $(0.01)$ & yes & no $(0.00)$ \\
\hline 13 & no & yes $(0.25)$ & yes & no $(0.01)$ & yes & no $(0.00)$ \\
\hline
\end{tabular}

* Probability of LR statistic in parenthesis. Full sample: 06/01/89 - 25/4/2003, pre-EMU period: 06/01/89 - 25/12/1998, EMU period: 01/1/1999 - 25/4/2003. 
Table 5: Tests for cointegration and for weak exogeneity (for daily realisations of the 1-month LIBOR rates)

\begin{tabular}{|c|c|c|c|c|c|c|}
\hline \multirow{2}{*}{$\begin{array}{l}\text { Lag } \\
\text { length in } \\
\text { working } \\
\text { days }\end{array}$} & \multicolumn{2}{|c|}{ Full sample: 89-2003 } & \multicolumn{2}{|c|}{ Pre-EMU 89-98 } & \multicolumn{2}{|c|}{ EMU 99-2003 } \\
\hline & $\begin{array}{l}\text { Cointegration } \\
\text { IUS IEU } \\
\text { (yes or no, at } \\
5 \% \text { level, trace } \\
\text { and max- } \\
\text { eigenvalue test }\end{array}$ & $\begin{array}{l}\text { Weak } \\
\text { exogeneity of } \\
\text { IUS } \\
\text { (yes or no)* }\end{array}$ & $\begin{array}{l}\text { Cointegration } \\
\text { IUS IEU } \\
\text { (yes or no, at } \\
5 \% \text { level, trace } \\
\text { and max- } \\
\text { eigenvalue test }\end{array}$ & $\begin{array}{l}\text { Weak } \\
\text { exogeneity of } \\
\text { IUS } \\
\text { (yes or no)* }\end{array}$ & $\begin{array}{l}\text { Cointegration } \\
\text { IUS IEU } \\
\text { (yes or no, at } \\
5 \% \text { level, trace } \\
\text { and max- } \\
\text { eigenvalue test }\end{array}$ & $\begin{array}{l}\text { Weak } \\
\text { exogeneity of } \\
\text { IUS } \\
\text { (yes or no)* }\end{array}$ \\
\hline 1 & yes & yes $(0.14)$ & $\begin{array}{l}\text { yes (for both } 5 \\
\text { and } 1 \text { percent) }\end{array}$ & no $(0.00)$ & $\begin{array}{l}\text { no (none of the } \\
\text { series with a } \\
\text { unit root, } \\
\text { stationary VAR } \\
\text { in levels) }\end{array}$ & no $(0.00)$ \\
\hline 5 & yes & yes $(0.37)$ & $\begin{array}{l}\text { yes (for both } 5 \\
\text { and } 1 \text { percent) }\end{array}$ & no $(0.01)$ & no & no $(0.01)$ \\
\hline 10 & yes & yes $(0.66)$ & yes & no $(0.01)$ & no & no $(0.01)$ \\
\hline 21 & $\begin{array}{l}\text { yes (for both } 5 \\
\text { and } 1 \text { percent) }\end{array}$ & yes $(0.42)$ & $\begin{array}{l}\text { yes (for both } 5 \\
\text { and } 1 \text { percent) }\end{array}$ & no $(0.04)$ & $\begin{array}{l}\text { no (none of the } \\
\text { series with a } \\
\text { unit root, } \\
\text { stationary VAR } \\
\text { in levels) }\end{array}$ & no $(0.00)$ \\
\hline 42 & $\begin{array}{l}\text { yes (for both } 5 \\
\text { and } 1 \text { percent) }\end{array}$ & yes $(0.53)$ & yes & yes $(0.58)$ & yes & no $(0.00)$ \\
\hline
\end{tabular}

* Probability of LR statistic in parenthesis. Full sample: 08/05/89 - 08/05/2003,

pre-EMU period: 08/05/89 - 31/12/1998, and EMU period: 01/1/1999 - 08/05/2003.

For weekly data there are only a few indications of cointegration between the euro and the US interest rates, if we include the Bundesbank years. Only in case of long lags ( 9 and 13 weeks) both series appear to be cointegrated. If we limit our analysis to the euro period, we often have to conclude that none of the series has a unit root, and a stationary VAR may be specified in terms of the levels of all of the interest rate series. Again, only in case of 9-week and 13-week lags there is evidence of cointegration. For the EMU period, there is no evidence of weak exogeneity of the US interest rate at all. Even in the case of long lags ( 9 and 13 weeks) with clear evidence of cointegration, the euro and the US interest rates seemed to have moved together without any signs of the US rate being the driving force behind this comovement. Both for the total period and for the DM period, there is no evidence for cointegration an, hence, no need for us to consider cases of weak exogeneity for these samples. 
In case of daily data and the long sample from 1989 to 2003, the evidence for cointegration becomes stronger, the larger the number of lags is (again evidence in favour of cyclicality" and against "policy coordination"). In addition, the US interest rate cannot be rejected to be weakly exogenous. Hence, one might conclude that in this case the hypothesis "The ECB follows the Fed" is corroborated empirically. However, one should be careful with this interpretation since this test does not take into account the structural break induced by the introduction of the euro. For daily data and the other two samples under investigation, there is no evidence of weak exogeneity of the US interest rate. In some cases the cointegration tests indicate that none of the series has a unit root and a stationary VAR may be specified in terms of the levels of both the euro and the US interest rate, although the individual unit root tests conveyed the impression that some of the series are integrated of order $1 .^{15}$

\section{Does the relationship change over time?}

Our main finding so far has been that for the EMU period one does not find an asymmetric and one way influence of the Fed on the ECB. However, just as there was a clear structural break around the start of EMU there might have been another break within the EMU period. Our main candidate for a structural break is September (to be more precise $11^{\text {th }}$ of September) 2001 , because this started a period of unprecedented political and financial market instability. Our second candidate is in the run-up to the first one, namely the turn-of-year 2000/01 with the uncertainty about an unravelling of the financial equilibrium in the US economy. As explained in the introduction we consider that this (combined) increase in uncertainty should lead to an asymmetry in monetary policy because the increase in uncertainty increases the 'option value of waiting' for policy makers much more in the Euro area, whose economic system is much less flexible than that of the US.

\subsection{The role of the $11^{\text {th }}$ of September 2001: Evidence based on GC Tests}

In order to test this kind of reasoning, we expend some efforts to search for breaks in the relation between US and euro interest rates around September $11^{\text {th }}, 2003$ via the Granger causality test procedure. For this purpose, we again split up the EMU sample in two subperiods. This time, the first sub-sample ranges from 1999 until the $11^{\text {th }}$ of September 2001

\footnotetext{
${ }^{15}$ An alternative interpretation would be that this apparent contradiction to the results of our unit root tests may be the result of low power of the cointegration tests conducted which is perhaps due to a too small sample size or a specification error. If the latter is the case, this would be evidence for a more complicated relationship between euro and US interest rates than implied by a simple follower-leadership hypothesis tested in this paper.
} 
and the second comprises the dates from $12^{\text {th }}$ of September 2001 until 'today'. We conducted the tests for Granger-causality for the same three variables than before: the central bank rates (levels and differences), the weekly (only differences) and the daily realisations (only differences) of the 1-month money market rate. The results are displayed graphically in Figures 5 to 7 below. Like before, we plot the sequence of probability values dependent on the lag structure jointly with the 5 percent significance level. We again feel legitimized to accept the hypothesis of the ECB following the Fed as a one-way causality exactly if the pvalues are below 5 percent for the null hypothesis "The US rate does not GC the euro rate", but at the same time the p-values are above 5 percent for the null hypothesis "The euro rate does not GC the US rate". In other words, we expect the Fed to GC the ECB, but a the same time the ECB not to GC the Fed. This time we focus on the difference in results across the sub-samples before and after the 11th of September.

Figure 5: P-values for Granger Causality tests of central bank rates (sample split at September $11^{\text {th }}$ 2001)

a) For levels
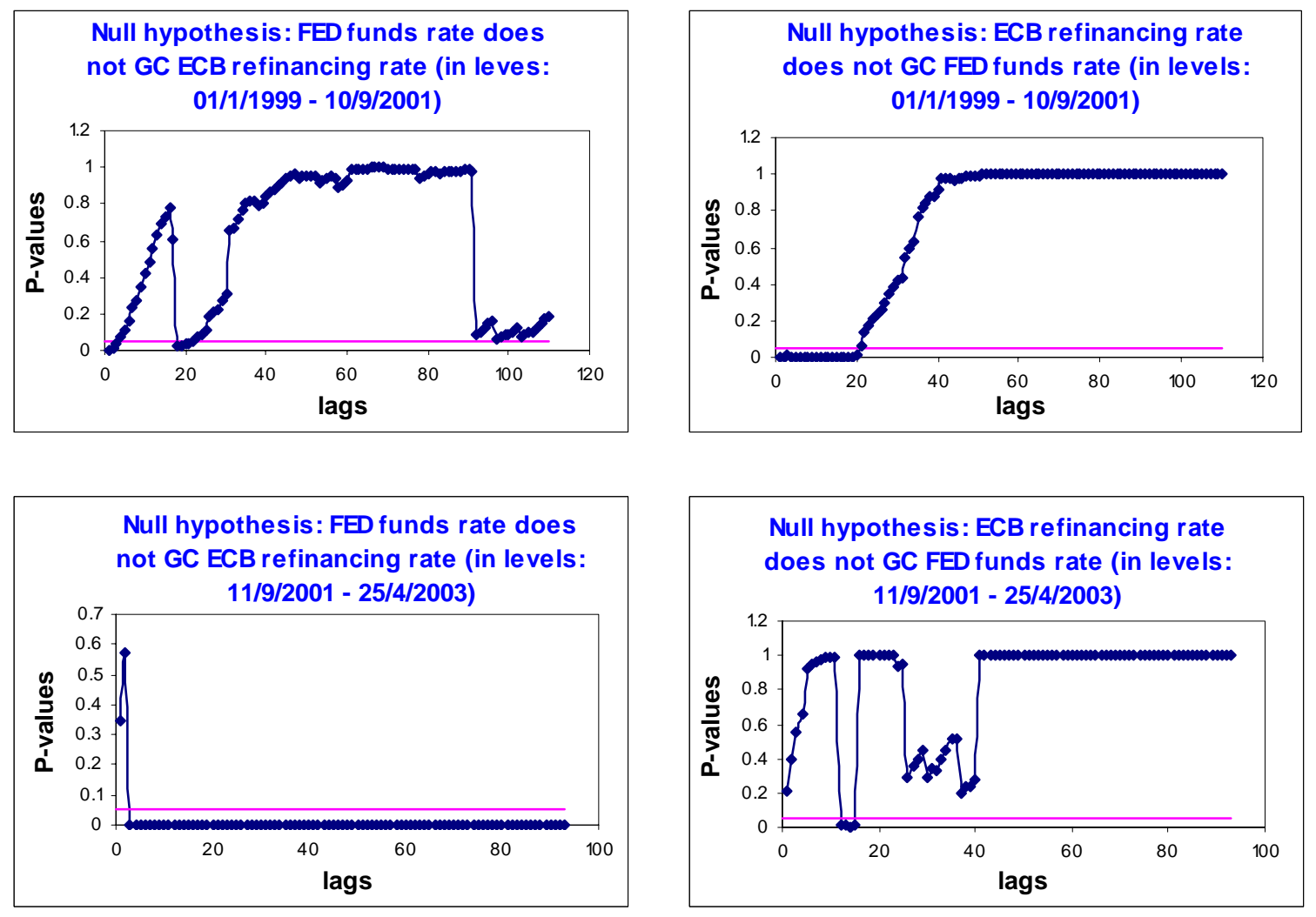

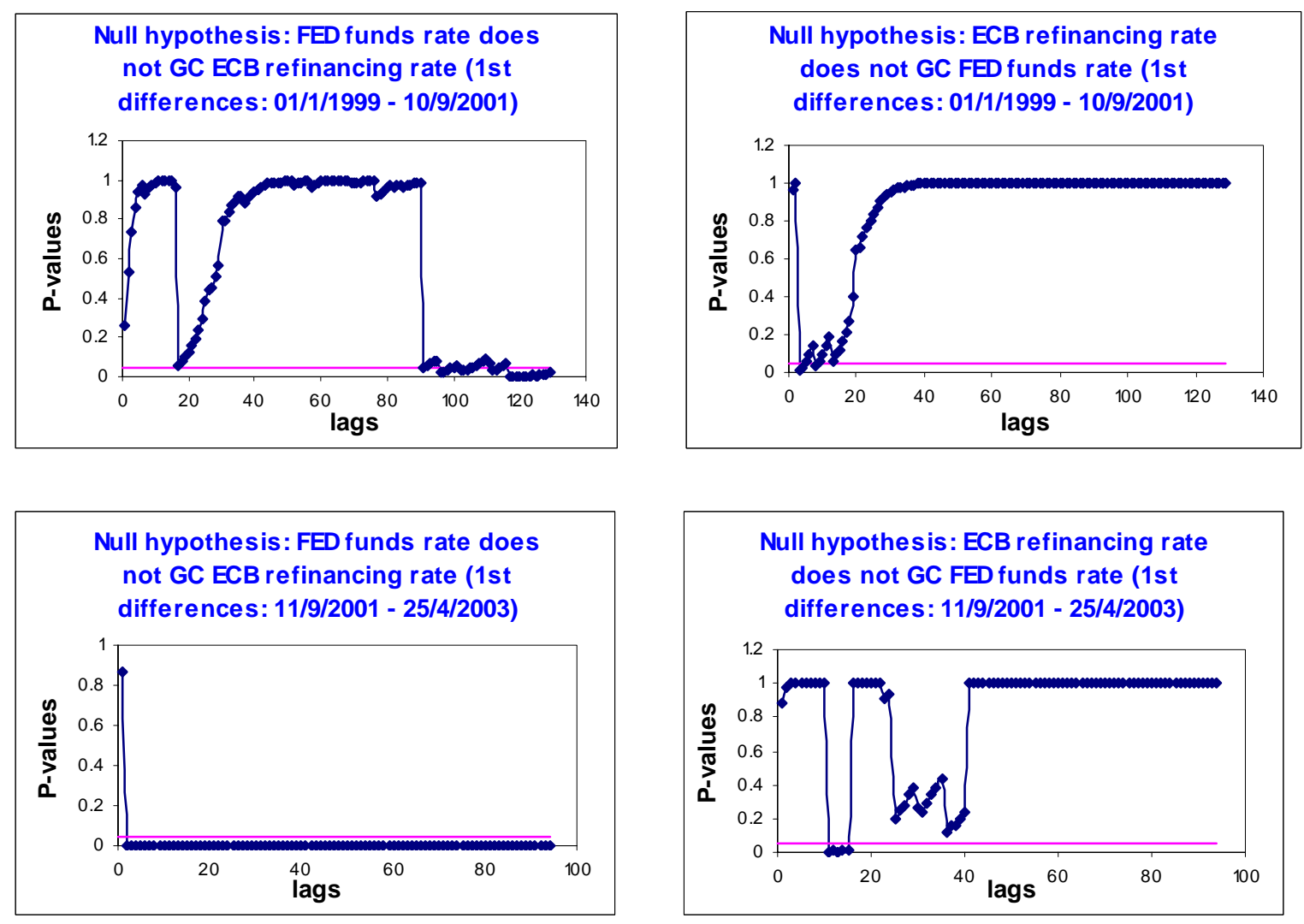

Figure 6: P-values for Granger Causality tests of weekly realisations of the 1-month LIBOR rates for first differences (sample split at September $11^{\text {th }}$ 2001)
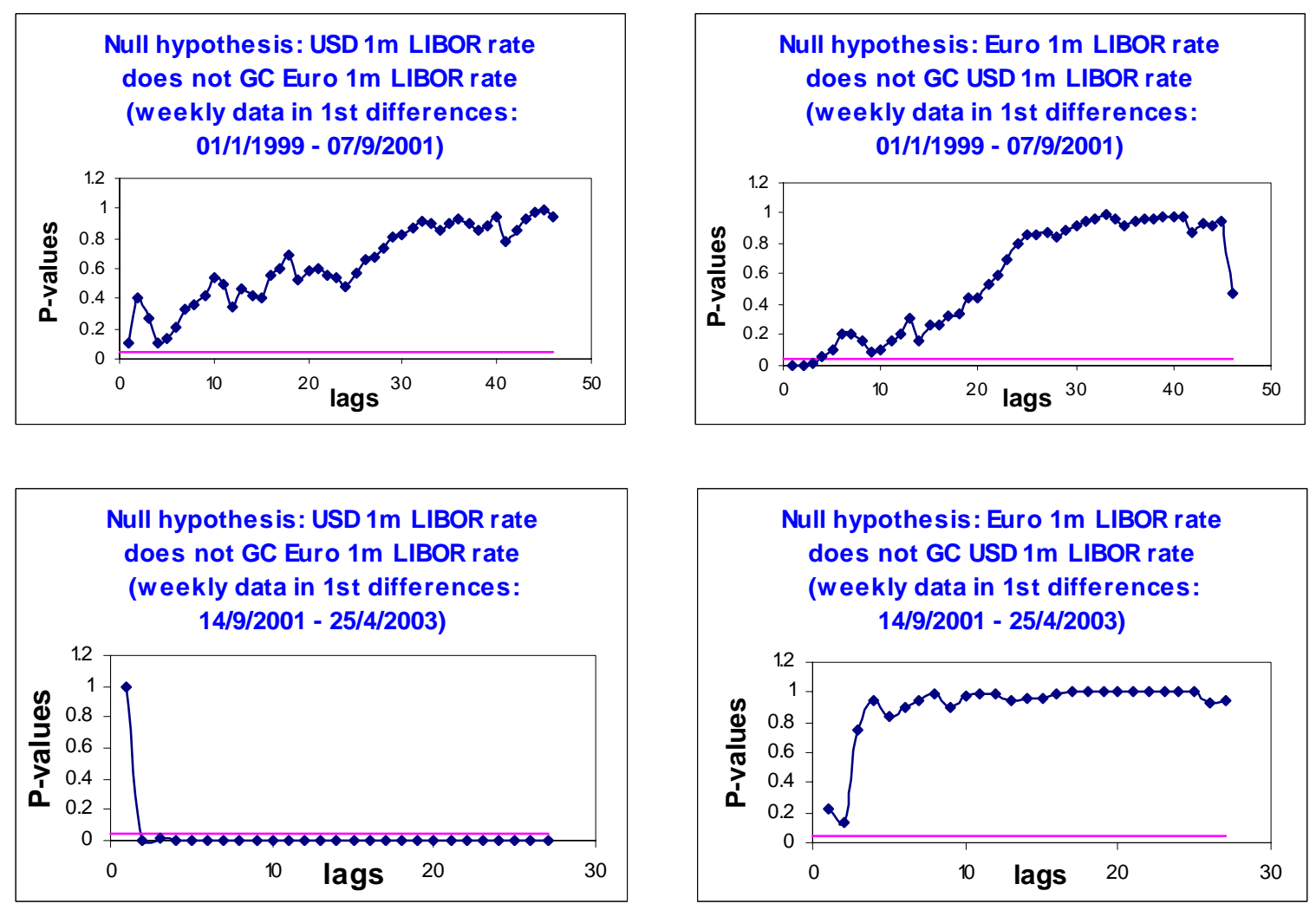
Figure 7: P-values for Granger Causality tests of daily realisations of the 1-month LIBOR rates for first differences (sample split at September $11^{\text {th }}$ 2001)
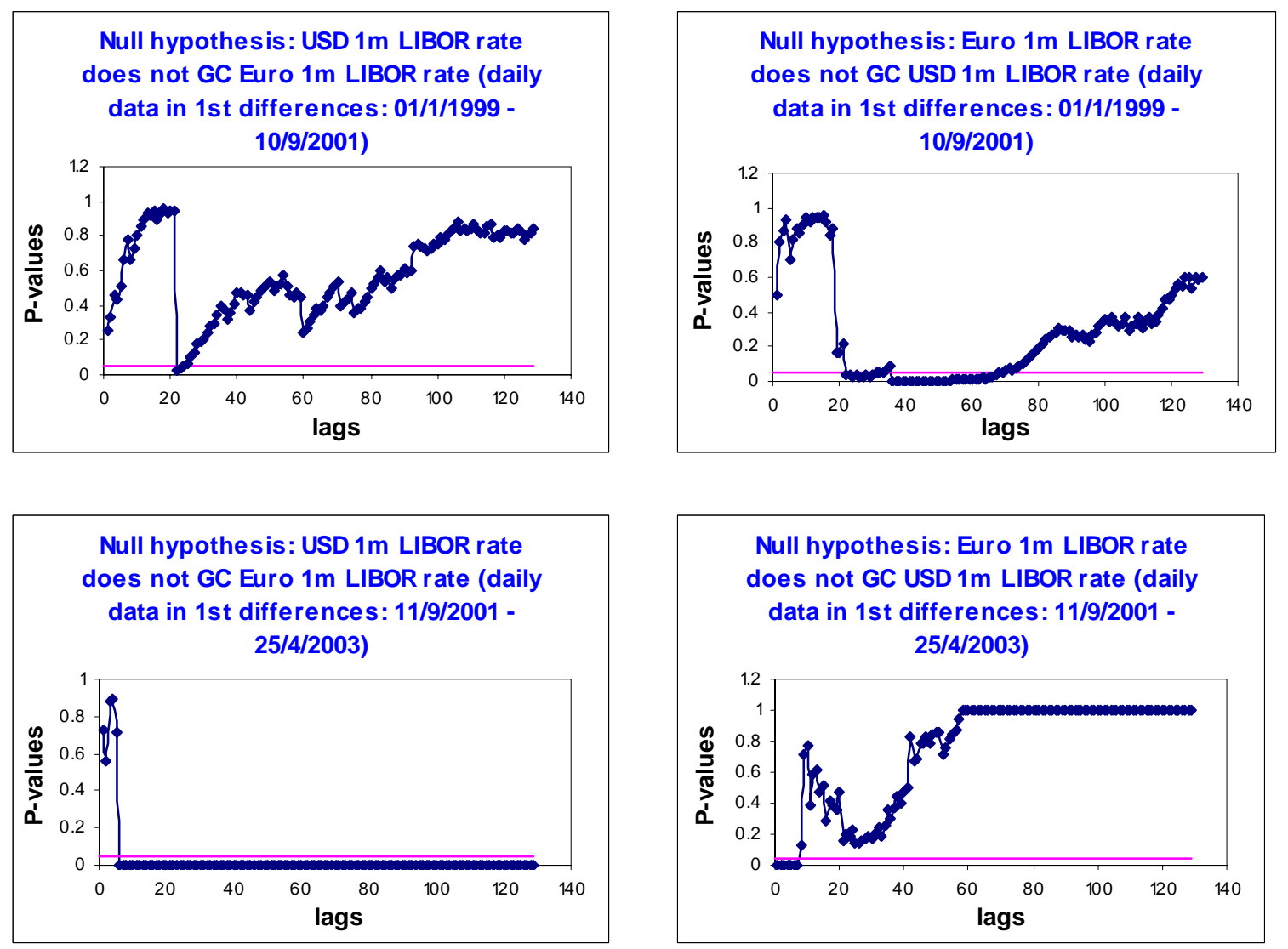

The results of our sample-split tests are striking. While there is no evidence that the ECB followed the Fed before the $11^{\text {th }}$ of September, it seems as if the ECB has done so afterwards. After September $11^{\text {th }}$, the Fed Granger causes the ECB, but at the same time the ECB does not Granger cause the Fed. Hence, changes in the euro interest rate appear to follow changes in the US rate by one-way causation. A leader-follower pattern according to the option value of waiting emerges. Moreover, the difference between the levels of the interest rates still remains high (see Figure 1). Hence, the option value of waiting with interest decisions also manifests itself in this level difference. All in all, our findings are consistent with the pattern that September $11^{\text {th }}, 2001$, raised the uncertainty for monetary policy making in addition to the generally observed rising uncertainty near turning points of the cycle. ${ }^{16}$

In the introduction, we indicated that we need an uncertainty threshold to trigger on the option argument. Testing for the existence of causality while controlling for the degree of uncertainty might constitute an interesting exercise. Equally, evidence of an "asymmetric "leaderfollower" relationship seems to emerge in a period of extraordinary uncertainty. After that, is

\footnotetext{
${ }^{16}$ For a general discussion of interest rate decisions in an uncertain environment see Begg et al. (2002), pp. 31ff.
} 
it business as usual? We briefly check this hypothesis indirectly, and track two market indicators of uncertainty in the stock markets, one for the US (VIX) and one for the euro area (VDAX). VIX is the North American S\&P Volatility Index (see Figure 8). The VDAX is an index which measures the variation of German stock futures (three months ahead). The source is Datastream Primark.

Figure 8: Stock market volatility in the US and in the Euro Area (VIX and VDAX)

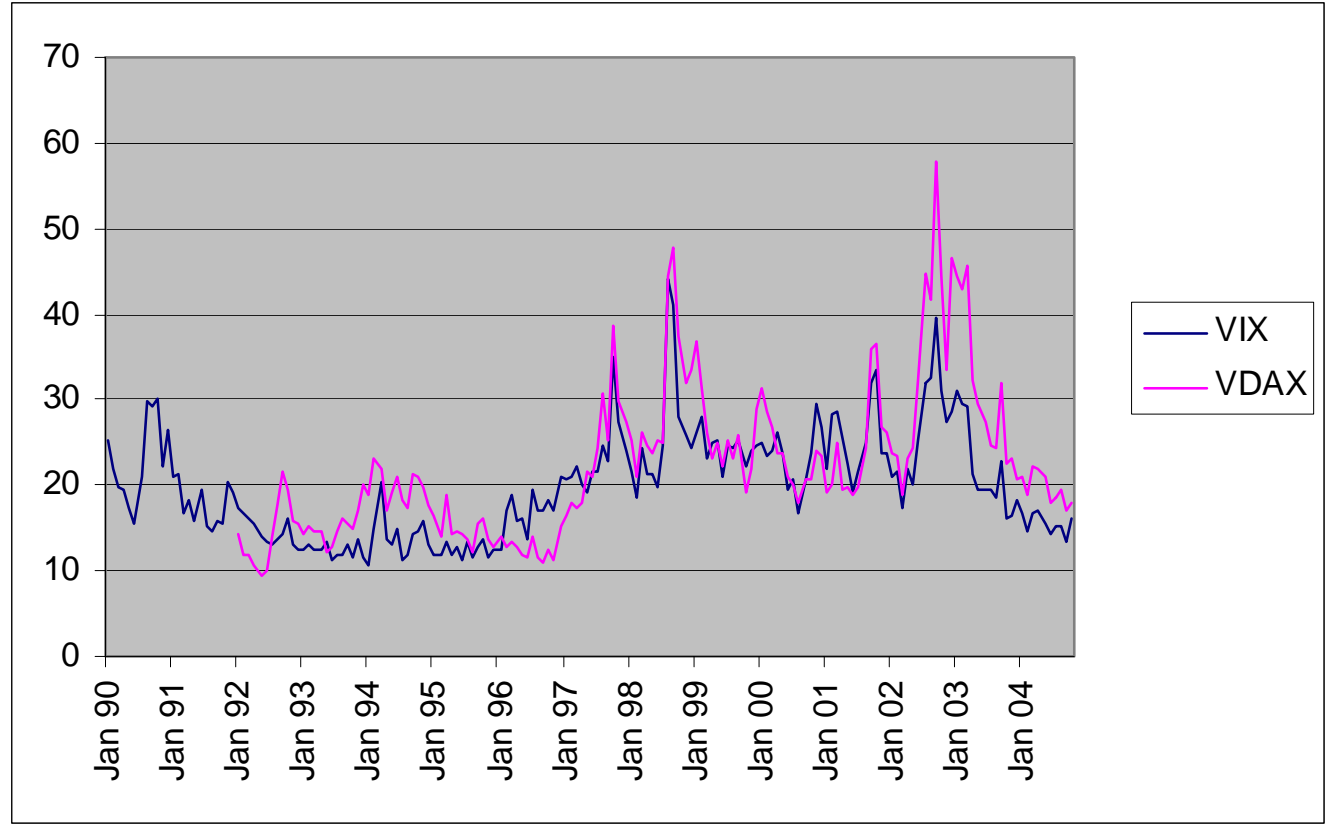

Source: Datastream Primark.

This figure suggests that EMU coincided with a major increase in uncertainty. Volatility is on average much lower during most of the 1990s. Around 1998 one observes a major increase in volatility (probably connected with the series of emerging market crisis, rather than EMU). Volatility not only increases, it also becomes more volatile, with a particularly strong increase in the last period used by us, which goes from end 2001 until early 2003. This makes our results appear plausible. Moreover, during this period uncertainty is consistently higher for the euro area than for the US which strengthens our main argument that the option value of waiting should be higher for the ECB than for the US since labour and goods market rigidities are higher in the euro area than in the US.

\subsection{Breaks around the turn-of-year 2000/01? Evidence based on GC tests}

One might still argue that interest rates in Europe tended to be influenced by what had happened on the other side of the Atlantic but that this had changed during 2001. In that year 
the Fed cut interest rates at an unprecedented speed (and by an unprecedented magnitude) because it feared an unravelling of the financial equilibrium in the US. The ECB took a more relaxed stance on this point as the euro area economy did not show any of the (potential) disequilibria of the US economy (current account, consumer financial position, overinvestment). For the ECB interest rate setting, this might have induced uncertainty and an option value of waiting. Hence, one might be tempted to conclude that over the whole sample the relationship between the US and the euro interest rate was contemporaneous, while a leader-follower relationship with the Fed as the leader becomes significant if only two subsamples of the EMU period (namely until December 2000) are considered. In order to test whether this kind of reasoning is correct, we take some efforts to search for breaks in the relation between US and euro interest rates around the turn of year 2000-01.

For this purpose, we again split up the EMU sample in two sub-periods. This time, the first sub-sample ranges from 1999 until the end-of-year 2000 and the second comprises the dates from 2001 until 'today'. We conducted the tests for Granger-causality for the same three variables than before: the central bank rates (levels and differences), the weekly (only differences) and the daily realisations (only differences) of the 1-month rate. A representative selection of the results is displayed graphically in Figures 8 and 9. Like before, we plot the sequence of probability values dependent on the lag structure jointly with the 5 percent significance level. We again regard the hypothesis of the ECB following the Fed as a one-way causality as corroborated if the p-values are below 5 percent for the null hypothesis "The US rate does not GC the euro rate", but at the same time the p-values are above 5 percent for the null hypothesis "The euro rate does not GC the US rate". However, this time we focus on the difference in results across the sub-samples before and after the turn-of-year 2000/01. We only display the results for the first differences of the central bank rates and of the weekly realisations of the 1-month LIBOR rates (Figures 9 and 10). ${ }^{17}$

\footnotetext{
${ }^{17}$ The tests for the remaining variables display a similar pattern and are available on request.
} 
Figure 9: P-values for Granger Causality tests of central bank rates (sample split at turn-of-year 2000/01)
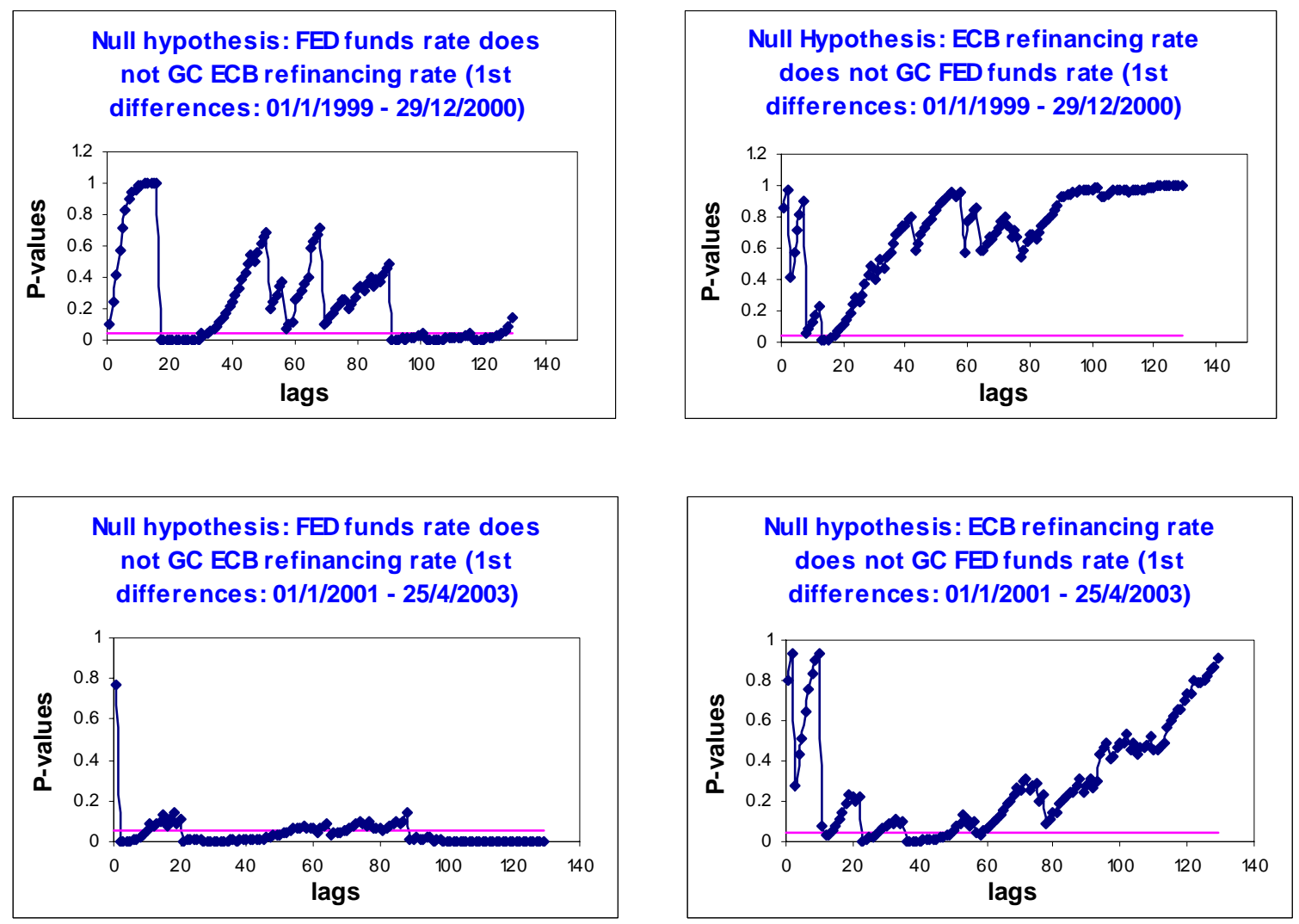

Figure 10: P-values for Granger Causality tests of weekly realisations of 1-month LIBOR rates for first differences (sample split at turn-of-year 2000/01)
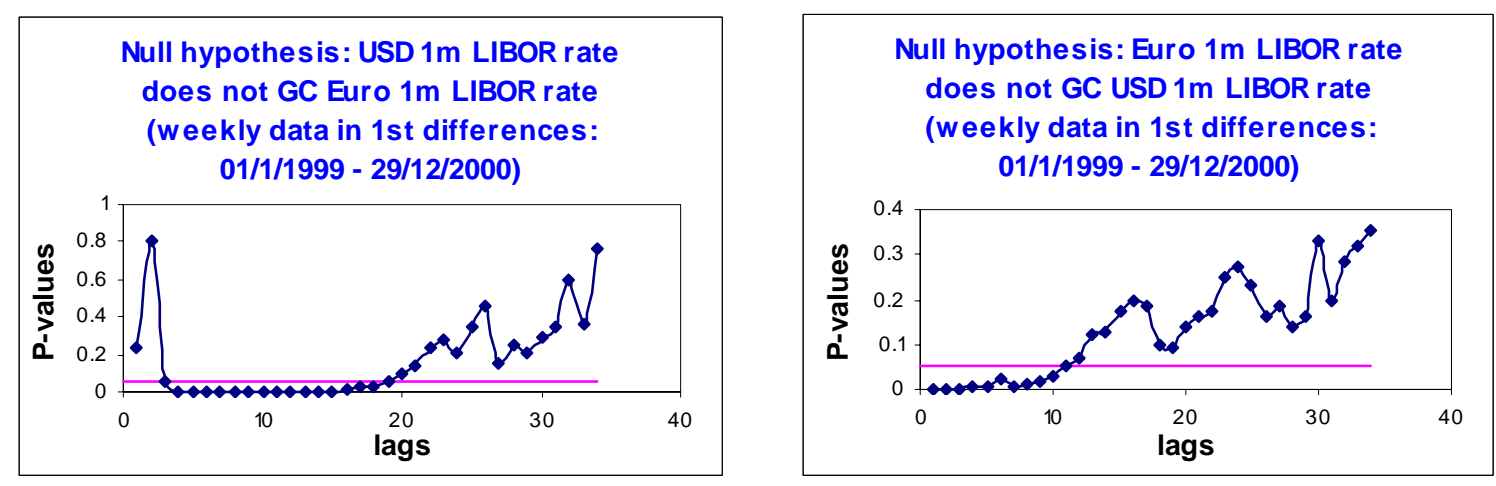

Null hypothesis: USD 1m LIBOR rate does not GC Euro 1m LIBOR rate (weekly data in 1st differences: 05/1/2001 - 25/4/2003)

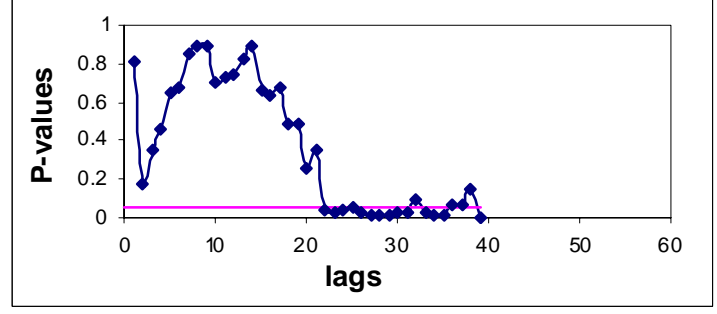

Null hypothesis: Euro 1m LIBOR rate does not GC USD 1m LIBOR rate (weekly data in 1st differences: 05/1/2001 - 25/4/2003)

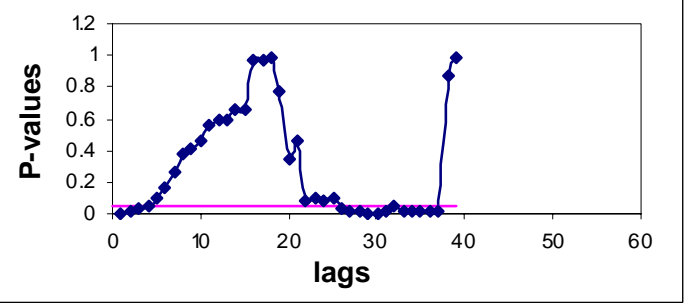


With respect to the results for weekly data the main impression is that before the suspected break there is a two-way causation between the US interest rate and the euro interest rate for short lags (from 4 to 10 weeks). After this potential break, this mutual impact of US and euro interest rates can be established only for longer lags (from 23 weeks on). Moreover, for very short lags there is even evidence for the ECB leading the Fed. However, for the central bank rates, the evidence for the leader-follower hypothesis after the break is much stronger. All in all and although evidence appears to a certain extent weaker, already the turn-of-year 2000/01 (combined with September 2001) represents the starting point for higher general uncertainty which is strong enough to induce for the ECB an option value of waiting with interest rate decisions. $^{18}$

\section{Conclusions}

So does the ECB follow the Fed ${ }^{19}$ Our answer would be: no, except for the period after the turn-of-year 2000/01 and, more significantly, September 2001. To be more precise, we find that the relationship between the interest rate decisions of the Fed and the ECB changes over time. Most of the time it is symmetric. Only after September 2001 do we find a preponderance of the evidence hinting at a significant influence of the US on the euro area, but little in the other direction. However, a note of caution applies here. Since the merger of European national central banks almost certainly resulted in a change of the parameters of the central bank reaction function, the length of the time period which has elapsed since the start of EMU respectively since September $11^{\text {th }}$ is only beginning to be sufficient for our empirical tests. Hence, one should find even more investigations of this highly relevant topic in the future.

What could account for this finding? One hypothesis mentioned in the introduction is that the cyclical position of Euroland lags that of the US, implying that the leader-follower relationship might be spurious. However, the US business cycle has led the euro area one for quite some time now, but we find that the Fed leads the ECB only during the most recent

\footnotetext{
${ }^{18}$ Begg et al. (2002) report in their MECB 4 update that since September 2001, the economic environment has become dramatically more uncertain. In this respect, they refer to, e.g. the sharp drop in stock markets, the large swings in HICP inflation largely unconnected with food or energy prices.

${ }^{19}$ The ECB has, understandably, not taken any position on this issue. But a recent ECB Working Document (Ehrmann and Fratzscher 2002) analyses one part of this issue, namely the extent to which the US influences the euro area. The conclusions are interesting: "There are in particular some US macroeconomic announcements to which European markets react significantly, especially in times of increased uncertainty, like the initial period of EMU or the 2001 recession" and, "throughout a learning process, the importance given to US news has declined". As will become clearer below our own results are consistent with the first quote, but go in the opposite direction of the second quote.
} 
period. The emergence of an asymmetric leader-follower relationship renders less likely the popular explanation that the ECB is just slow because it is a new institution that has to find its way in unfamiliar territory. If this had been the case, one would have expected to find evidence for the hypothesis that the Fed leads the ECB mainly during the early EMU period, not more recently.

It is always difficult to determine the deeper reasons for correlations over time. But the fact that the asymmetric leader-follower relationship appears only after a major shock which increases global uncertainty suggests to us that the deeper reason why the ECB appears to follow the Fed is simply that the Euro area economy is less flexible. This makes it optimal also for the ECB to take into account the "option value of waiting" and react later to shocks. This implies that even if both economies are hit mainly by common shocks (Peiró 2002) one would find econometrically that the Fed seems to be leading the ECB. From this perspective, common shocks imply that the US interest cycle leads the EU if the US is more flexible and also contracts more quickly in response to negative shocks. In contrast to Begg et al. (2002), we do not argue that such rigidities may require monetary policy to play a bigger role. Instead, waiting with interest rate changes becomes valuable if there is a large degree of uncertainty.

We see three directions for further research in this area. First, due to particular pitfalls of applying Granger causality tests to the issue of policy coordination autoregressive conditional hazard specifications could be used which allows one to produce dynamic forecasts of the probability of a change in the interest rate target (Hamilton and Jordá 2000, Bergin and Jordá 2002). Methods of survival analysis can be applied to test whether a change in the targeted fund rate puts the ECB under pressure to change its refi rates in the same direction, supposing an increasing "risk", in other words a rising hazard rate. The duration between a decision of the Fed and a possible reaction of the ECB will be defined as "survival time" (time on risk). This variable will further be assumed to depend not only on time but also on the reaction function of the ECB that mainly contains the preference for low inflation.

Second, as indicated by our cointegration results one could use VARs in levels or singleequation error-correction models: In cases where our tests in Table 5 indicate cointegration and weak exogeneity. Tests of weak exogeneity of the US interest rate should be conducted in order to test the hypothesis, that this single vector has to be implemented only in the ECM formulated for the European interest rate. Only if weak exogeneity cannot be rejected and the coefficient estimate of the lagged change in the US interest rate reveals a positive sign, the 
ECM can in a strict sense be interpreted as a function expressing that the ECB (Bundesbank) has followed the Fed.

Third, one could test for the hypothesis that the Fed seems to influence the ECB but not vice versa, based on a joint estimation of Taylor-type reaction functions of the two central banks. The hypothesis could be tested by incorporating the decision variable of one central bank into the other central bank's reaction function (Ulrich 2003). ${ }^{20}$ However, the shortage of the observation period so far has largely prevented estimates of reliable Taylor functions for the ECB. Before any reliable results will emerge, significant problems of calibrating parameters versus estimating pre-EMU aggregate data will have to be solved in a satisfying way. Moreover, the specification of the reaction functions is still open to debate. Theoretically, a related question would be to ask how the Fed would have reacted if it were responsible for the euro area economy after September $11^{\text {th }}$ (see, e.g., Begg et al. 2002, pp. 41 ff., Wyplosz 2001). Would the Fed also have been governed by the option value of waiting and thus lowered interest rates less than it did for the US? This leads one to another transatlantic difference the ECB and the Fed have somewhat different mandates (narrow mandate to maintain price stability in the medium run versus broad mandate to promote stable prices and maximum employment).

Starting in late 2003, global financial markets have entered a much calmer period. During this period the leader-follower relationship observed in the immediate aftermath of September 2001 seems to have disappeared as the Federal Reserve has started to increase systematically interest rates in small steps whereas the ECB has not changed its rates for over two years. However, it is too early to proclaim the definite 'independence' of the ECB from the Fed since too little time has passed and a data from a low volatility period makes it always difficult to refute any starting hypothesis.

\footnotetext{
${ }^{20}$ In the light of the results of this paper, the significance of the funds rate in the ECB's reaction function according to Ulrich (2003) can be characterised as a spurious correlation. Monetary policy is empirically rejected to be a game of "follow my leader", but of setting the right policy under uncertainty in the light of domestic inflation and growth prospects.
} 


\section{References}

Banerjee, A., et al. (1993): Co-Integration, Error-Correction, and the Econometric Analysis of Non-stationary Data, Oxford.

BBC-News (2001): Europe Defies Calls for Rate Cut, BBC News Business, Web: http://news.bbc.co.uk/1/hi/business/1412137.stm, access May 2 $2^{\text {nd }}, 2003$.

Begg, D., F. Canova, de Grauwe, P., Fatás, A., and P. Lane (2002): Surviving the Slowdown, Monitoring the European Central Bank 4, Centre for Economic Policy Research (CEPR), London.

Belke, A., Goecke, M. (2003): Monetary Policy (In-) Effectiveness Under Uncertainty - Some Normative Implications for European Monetary Policy, Diskussionsbeiträge aus dem Institut für Volkswirtschaftslehre, no. 223/2004, University of Hohenheim, Stuttgart.

Belke, A., Gros, D. (2002): Designing EU-US Monetary Relations: The Impact of Exchange Rate Variability on Labor Markets on Both Sides of the Atlantic, World Economy 25, pp. 789-813.

Belke, A., Gros, D. (2002a): Does the ECB Follow the Fed?, Department of Economics Discussion Paper 211/2002, University of Hohenheim, Stuttgart.

Belke, A., Koesters, W., Leschke, M., and T. Polleit (2002): International Coordination of Monetary Policies - Challenges, Concepts and Consequences, ECB-Observer - Analyses of the Monetary Policy of the European System of Central Banks 4, December, Frankfurt, Part 1: Impact of Exchange Rate Volatility on Labour Markets - a Case for Transatlantic Monetary Policy Coordination?.

Bergin, P.R., and Jordá, O. (2002): Measuring Monetary Policy Interdependence, forthcoming: Journal of International Money and Finance.

Borio, C. (2001): Comparing Monetary Policy Operating Procedures Across the United States, Japan, and the Euro Area, BIS Paper 9, Bank for International Settlements, Basle, pp. 1-22.

Breuss, F. (2002): Is ECB's Monetary Policy Optimal Already?, Paper Presented at the International Conference on Policy Modelling, EcoMod, July 4-6, Brussels.

Ehrmann, M., Fratzscher, M. (2002): Interdependence Between the Euro Area and the US: What Role for EMU?, European Central Bank Working Paper 200, December, Frankfurt.

Fischer, A.M., Peytrignet, M. (1991): The Lucas Critique in the Light of Swiss Monetary Policy, Oxford Bulletin of Economics and Statistics 53, pp. 481-493.

Fratianni, M., von Hagen, J. (1990): German Dominance in the EMS: Evidence from Interest Rates, Journal of International Money and Finance 9, pp. 358-375.

Garcia-Cervero, S. (2002): Is the FED Really Leading the Way?, Deutsche Bank Europe Weekly 22 November 2002, Global Markets Research, London, pp. 8-10.

Greene, W.H. (2003): Econometric Analysis, $5^{\text {th }}$ ed., New Jersey.

Gros, D., Belke, A. (2003): If the ECB Cuts Rates It Should Do So Boldly, Financial Times International, Comment \& Analysis, March 2nd, p. 13. 
Gros, D. Durrer, K., Jimeno, J., Monticelli, C., Perotti, P., Daveri, F. (2002): Fiscal and Monetary Policy for a Low-speed Europe, $4^{\text {th }}$ Annual Report of the CEPS Macroeconomic Policy Group, Centre for European Policy Studies, Brussels.

Hamilton, J.D., Jordá, O. (2000): A Model for the Federal Funds Rate Target, NBER Working Paper 7847, National Bureau of Economic Research, Cambridge/MA.

Hendry, D.F. (1993): The Roles of Economic Theory and Econometrics in Time Series Economics, Paper presented at the 1993 Meeting of the European Econometric Society, Oxford, mimeo.

Johansen, S. (1991): Estimation and Hypothesis Testing of Cointegration Vectors in Gaussian Vectorautoregressive Models, Econometrica 59, pp. 1551-1580.

Johansen, S. (1995): Likelihood-based Inference in Cointegrated Vector Autoregressive Models, Oxford University Press.

Peiró, A. (2002): Macroeconomic Synchronization between G3 Countries, German Economic Review 3(2), pp. 137-53.

Perez-Quiros, G., Sicilia, J. (2002): Is the European Central Bank (and the United States Federal Reserve) Predictable?, European Central Bank Working Paper 192, November, Frankfurt

Perron, P. (1989): The Great Crash, The Oil Price Shock, and the Unit Root Hypothesis, Econometrica 57, pp. 1361-1401.

Schroeder, M. et al. (2002): Neue Übertragungsmechanismen in einer globalisierten Weltwirtschaft - Deutschland und Europa im internationalen Verbund, Gutachten für das Bundesministerium für Wirtschaft und Technologie, Centre for European Economic Research (ZEW) Mannheim, documented in Frankfurter Allgemeine Zeitung, June 7th, (2002): Der Einfluss der amerikanischen Konjunktur wird schwächer.

Ulrich, K. (2003): A Comparison Between the Fed and the ECB: Taylor Rules, ZEW Discussion Paper No. 03-19, Centre for European Economic Research, Mannheim.

Walton, D. et al. (2003): Can Euroland Accelerate Without US Fuel?, European Weekly Analyst 21, May 23, Goldman Sachs, London.

Wyplosz, C. (2001): The Fed and the ECB, Briefing Note to the Committee for Economic and Monetary Affairs of the European Parliament, September 12, Brussels. 


\title{
CESifo Working Paper Series
}

\author{
(for full list see www.cesifo.de)
}

1362 Christa Hainz, Quality of Institutions, Credit Markets and Bankruptcy, December 2004

1363 Jerome L. Stein, Optimal Debt and Equilibrium Exchange Rates in a Stochastic Environment: an Overview, December 2004

1364 Frank Heinemann, Rosemarie Nagel and Peter Ockenfels, Measuring Strategic Uncertainty in Coordination Games, December 2004

1365 José Luis Moraga-González and Jean-Marie Viaene, Anti-Dumping, Intra-Industry Trade and Quality Reversals, December 2004

1366 Harry Grubert, Tax Credits, Source Rules, Trade and Electronic Commerce: Behavioral Margins and the Design of International Tax Systems, December 2004

1367 Hans-Werner Sinn, EU Enlargement, Migration and the New Constitution, December 2004

1368 Josef Falkinger, Noncooperative Support of Public Norm Enforcement in Large Societies, December 2004

1369 Panu Poutvaara, Public Education in an Integrated Europe: Studying to Migrate and Teaching to Stay?, December 2004

1370 András Simonovits, Designing Benefit Rules for Flexible Retirement with or without Redistribution, December 2004

1371 Antonis Adam, Macroeconomic Effects of Social Security Privatization in a Small Unionized Economy, December 2004

1372 Andrew Hughes Hallett, Post-Thatcher Fiscal Strategies in the U.K.: An Interpretation, December 2004

1373 Hendrik Hakenes and Martin Peitz, Umbrella Branding and the Provision of Quality, December 2004

1374 Sascha O. Becker, Karolina Ekholm, Robert Jäckle and Marc-Andreas Mündler, Location Choice and Employment Decisions: A Comparison of German and Swedish Multinationals, January 2005

1375 Christian Gollier, The Consumption-Based Determinants of the Term Structure of Discount Rates, January 2005

1376 Giovanni Di Bartolomeo, Jacob Engwerda, Joseph Plasmans, Bas van Aarle and Tomasz Michalak, Macroeconomic Stabilization Policies in the EMU: Spillovers, Asymmetries, and Institutions, January 2005 
1377 Luis H. R. Alvarez and Erkki Koskela, Progressive Taxation and Irreversible Investment under Uncertainty, January 2005

1378 Theodore C. Bergstrom and John L. Hartman, Demographics and the Political Sustainability of Pay-as-you-go Social Security, January 2005

1379 Bruno S. Frey and Margit Osterloh, Yes, Managers Should Be Paid Like Bureaucrats, January 2005

1380 Oliver Hülsewig, Eric Mayer and Timo Wollmershäuser, Bank Loan Supply and Monetary Policy Transmission in Germany: An Assessment Based on Matching Impulse Responses, January 2005

1381 Alessandro Balestrino and Umberto Galmarini, On the Redistributive Properties of Presumptive Taxation, January 2005

1382 Christian Gollier, Optimal Illusions and Decisions under Risk, January 2005

1383 Daniel Mejía and Marc St-Pierre, Unequal Opportunities and Human Capital Formation, January 2005

1384 Luis H. R. Alvarez and Erkki Koskela, Optimal Harvesting under Resource Stock and Price Uncertainty, January 2005

1385 Ruslan Lukach, Peter M. Kort and Joseph Plasmans, Optimal R\&D Investment Strategies with Quantity Competition under the Threat of Superior Entry, January 2005

1386 Alfred Greiner, Uwe Koeller and Willi Semmler, Testing Sustainability of German Fiscal Policy. Evidence for the Period 1960 - 2003, January 2005

1387 Gebhard Kirchgässner and Tobias Schulz, Expected Closeness or Mobilisation: Why Do Voters Go to the Polls? Empirical Results for Switzerland, 1981 - 1999, January 2005

1388 Emanuele Bacchiocchi and Alessandro Missale, Managing Debt Stability, January 2005

1389 Assar Lindbeck and Dirk Niepelt, Improving the SGP: Taxes and Delegation rather than Fines, January 2005

1390 James J. Heckman and Dimitriy V. Masterov, Skill Policies for Scotland, January 2005

1391 Emma Galli \& Fabio Padovano, Sustainability and Determinants of Italian Public Deficits before and after Maastricht, January 2005

1392 Angel de la Fuente and Juan Francisco Jimeno, The Private and Fiscal Returns to Schooling and the Effect of Public Policies on Private Incentives to Invest in Education: A General Framework and Some Results for the EU, January 2005

1393 Juan C. Conesa and Carlos Garriga, Optimal Response to a Demographic Shock, January 2005 
1394 Christian Gollier, Optimal Portfolio Management for Individual Pension Plans, February 2005

1395 Ruslan Lukach, Joseph Plasmans and Peter M. Kort, Innovation Strategies in a Competitive Dynamic Setting, February 2005

1396 Gebhard Kirchgässner, (Why) Are Economists Different?, February 2005

1397 Marko Köthenbürger, Panu Poutvaara and Paola Profeta, Why are More Redistributive Social Security Systems Smaller? A Median Voter Approach, February 2005

1398 Gabrielle Demange, Free Choice of Unfunded Systems: A First Assessment, February 2005

1399 Carlos Fonseca Marinheiro, Sustainability of Portuguese Fiscal Policy in Historical Perspective, February 2005

1400 Roel M. W. J. Beetsma and Koen Vermeylen, The Effect of Monetary Unification on Public Debt and its Real Return, February 2005

1401 Frank Asche, Petter Osmundsen and Maria Sandsmark, Is It All Oil?, February 2005

1402 Giacomo Corneo, Media Capture in a Democracy: The Role of Wealth Concentration, February 2005

1403 A. Lans Bovenberg and Thijs Knaap, Ageing, Funded Pensions and the Dutch Economy, February 2005

1404 Thiess Büttner, The Incentive Effect of Fiscal Equalization Transfers on Tax Policy, February 2005

1405 Luisa Fuster, Ayşe İmrohoroğlu and Selahattin İmrohoroğlu, Personal Security Accounts and Mandatory Annuitization in a Dynastic Framework, February 2005

1406 Peter Claeys, Policy Mix and Debt Sustainability: Evidence from Fiscal Policy Rules, February 2005

1407 James M. Malcomson, Supplier Discretion over Provision: Theory and an Application to Medical Care, February 2005

1408 Thorvaldur Gylfason, Interview with Assar Lindbeck, February 2005

1409 Christian Gollier, Some Aspects of the Economics of Catastrophe Risk Insurance, February 2005

1410 Gebhard Kirchgässner, The Weak Rationality Principle in Economics, February 2005

1411 Carlos José Fonseca Marinheiro, Has the Stability and Growth Pact Stabilised? Evidence from a Panel of 12 European Countries and Some Implications for the Reform of the Pact, February 2005 
1412 Petter Osmundsen, Frank Asche, Bård Misund and Klaus Mohn, Valuation of International Oil Companies -The RoACE Era, February 2005

1413 Gil S. Epstein and Shmuel Nitzan, Lobbying and Compromise, February 2005

1414 Marcel F. M. Canoy, Jan C. van Ours and Frederick van der Ploeg, The Economics of Books, February 2005

1415 Eric A. Hanushek and Ludger Wößmann, Does Educational Tracking Affect Performance and Inequality? Differences-in-Differences Evidence across Countries, February 2005

1416 George Kapetanios and M. Hashem Pesaran, Alternative Approaches to Estimation and Inference in Large Multifactor Panels: Small Sample Results with an Application to Modelling of Asset Returns, February 2005

1417 Samuel Mühlemann, Jürg Schweri, Rainer Winkelmann and Stefan C. Wolter, A Structural Model of Demand for Apprentices. February 2005

1418 Giorgio Brunello and Lorenzo Rocco, Educational Standards in Private and Public Schools, February 2005

1419 Alex Bryson, Lorenzo Cappellari and Claudio Lucifora, Why so Unhappy? The Effects of Unionisation on Job Satisfaction, March 2005

1420 Annalisa Luporini, Relative Performance Evaluation in a Multi-Plant Firm, March 2005

1421 Giorgio Bellettini and Carlotta Berti Ceroni, When the Union Hurts the Workers: A Positive Analysis of Immigration Policy, March 2005

1422 Pieter Gautier, Michael Svarer and Coen Teulings, Marriage and the City, March 2005

1423 Ingrid Ott and Stephen J. Turnovsky, Excludable and Non-Excludable Public Inputs: Consequences for Economic Growth, March 2005

1424 Frederick van der Ploeg, Back to Keynes?, March 2005

1425 Stephane Dees, Filippo di Mauro, M. Hashem Pesaran and L. Vanessa Smith, Exploring the International Linkages of the Euro Area: a Global VAR Analysis, March 2005

1426 Hans Pitlik, Friedrich Schneider and Harald Strotmann, Legislative Malapportionment and the Politicization of Germany's Intergovernmental Transfer System, March 2005

1427 Konstantinos Angelopoulos and Apostolis Philippopoulos, The Role of Government in Anti-Social Redistributive Activities, March 2005

1428 Ansgar Belke and Daniel Gros, Asymmetries in the Trans-Atlantic Monetary Policy Relationship: Does the ECB follow the Fed?, March 2005 